Atmos. Chem. Phys., 17, 10125-10141, 2017

https://doi.org/10.5194/acp-17-10125-2017

(c) Author(s) 2017. This work is distributed under

the Creative Commons Attribution 3.0 License.

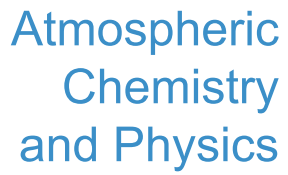

(c) (i)

\title{
Intercomparison of $\mathrm{NO}_{x}$ emission inventories over East Asia
}

\author{
Jieying Ding ${ }^{1,2}$, Kazuyuki Miyazaki ${ }^{3,4}$, Ronald Johannes van der $\mathbf{A}^{1,5}$, Bas Mijling ${ }^{1}$, Jun-ichi Kurokawa ${ }^{6}$, \\ SeogYeon Cho ${ }^{7}$, Greet Janssens-Maenhout ${ }^{8}$, Qiang Zhang ${ }^{9}$, Fei Liu ${ }^{1}$, and Pieternel Felicitas Levelt ${ }^{1,2}$ \\ ${ }^{1}$ Royal Netherlands Meteorological Institute (KNMI), De Bilt, the Netherlands \\ ${ }^{2}$ Delft University of Technology, Delft, the Netherlands \\ ${ }^{3}$ Japan Agency for Marine-Earth Science and Technology, Yokohama 236-0001, Japan \\ ${ }^{4}$ Jet Propulsion Laboratory-California Institute of Technology, Pasadena, USA \\ ${ }^{5}$ Nanjing University of Information Sciences and Technology, Nanjing, China \\ ${ }^{6}$ Asia Center for Air Pollution Research, Niigata, 950-2144, Japan \\ ${ }^{7}$ Department of Environmental Engineering, Inha University, Incheon, South Korea \\ ${ }^{8}$ Directorate for Energy, Transport and Climate, Joint Research Centre, Ispra, Italy \\ ${ }^{9}$ Department of Earth System Science, Tsinghua University, Beijing, 100084, China
}

Correspondence to: Jieying Ding (jieying.ding @knmi.nl)

Received: 21 March 2017 - Discussion started: 7 April 2017

Revised: 4 July 2017 - Accepted: 22 July 2017 - Published: 30 August 2017

\begin{abstract}
We compare nine emission inventories of nitrogen oxides including four satellite-derived $\mathrm{NO}_{x}$ inventories and the following bottom-up inventories for East Asia: REAS (Regional Emission inventory in ASia), MEIC (Multiresolution Emission Inventory for China), CAPSS (Clean Air Policy Support System) and EDGAR (Emissions Database for Global Atmospheric Research). Two of the satellitederived inventories are estimated by using the DECSO (Daily Emission derived Constrained by Satellite Observations) algorithm, which is based on an extended Kalman filter applied to observations from OMI or from GOME-2. The other two are derived with the EnKF algorithm, which is based on an ensemble Kalman filter applied to observations of multiple species using either the chemical transport model CHASER and MIROC-chem. The temporal behaviour and spatial distribution of the inventories are compared on a national and regional scale. A distinction is also made between urban and rural areas. The intercomparison of all inventories shows good agreement in total $\mathrm{NO}_{x}$ emissions over mainland China, especially for trends, with an average bias of about $20 \%$ for yearly emissions. All the inventories show the typical emission reduction of $10 \%$ during the Chinese New Year and a peak in December. Satellite-derived approaches using OMI show a summer peak due to strong emissions from soil and biomass burning in this season. Biases in $\mathrm{NO}_{x}$ emissions and uncertainties in temporal variability increase
\end{abstract}

quickly when the spatial scale decreases. The analyses of the differences show the importance of using observations from multiple instruments and a high spatial resolution model for the satellite-derived inventories, while for bottom-up inventories, accurate emission factors and activity information are required. The advantage of the satellite-derived approach is that the emissions are soon available after observation, while the strength of the bottom-up inventories is that they include detailed information of emissions for each source category.

\section{Introduction}

Emission sources are one of the crucial drivers for a chemical transport model (CTM). Accurate spatial and temporal emission distributions of air pollutants are important for air quality simulations and forecasts (Ma and van Aardenne, 2004; Eder et al., 2009; Zhang et al., 2012; Struzewska et al., 2016). Up-to-date emission information is also needed to help policy makers for efficient regulations to control air pollution. In general, two approaches are used to develop emission inventories. One approach is based on statistics combining local information such as emission activity rates and factors of different source categories (Streets et al., 2003). Here we refer to the inventories using this approach as bottomup inventories. This method results in detailed information 
on the type, source sector, fuel and technology. The countryspecific emissions are distributed in space with the location of the emissions using representative proxy data. Advances on temporal distribution are still needed to obtain representative maps that go beyond monthly resolution. However, large uncertainties are often introduced due to the uncertainties on all the input parameters in the calculation (Jaegle et al., 2005; Castellanos et al., 2014; Zheng et al., 2014; Li et al., 2016, 2017; Saikawa et al., 2017). It is also time consuming to collect all required information. Another approach to construct emission inventories is inverse modelling using satellite observations to constrain emissions by reducing the discrepancy between the modelled and observed concentrations and taking model and observation errors into account (Müller and Stavrakou, 2005; Konovalov et al., 2006; Sofiev et al., 2009; Miyazaki et al., 2012; Mijling et al., 2013; Streets et al., 2013; Stavrakou et al., 2016). In this study, the emissions derived with this approach are referred to as satellite-derived emissions. Since observations from satellite instruments like the Global Ozone Monitoring Experiment2 (GOME-2) and the Ozone Monitoring Instrument (OMI) achieve near-global coverage in a single day, we expect that emissions derived from these satellite observations are well constrained on a daily and global basis. A limitation of satellite-derived emission inventories is the difficulty to distinguish emissions from different source categories.

Nitrogen oxides $\left(\mathrm{NO}_{x}=\mathrm{NO}_{2}+\mathrm{NO}\right)$ play an important role in the formation of tropospheric ozone and secondary nitrate aerosols and in climate change (Jacob et al., 1996; Shindell et al., 2009). The emissions of air pollutants increased rapidly during the last two decades in East Asia due to the rapid economic development. Satellite observations as evidence show a strong increasing trend of $\mathrm{NO}_{2}$ column concentrations since 1995 in China (Irie et al., 2005; Richter et al., 2005; van der A et al., 2006). Akimoto and Narita (1994) built the first regional $\mathrm{NO}_{x}$ emission inventory for Asia at a resolution of $1^{\circ} \times 1^{\circ}$. Van Aardenne et al. (1999) estimated $\mathrm{NO}_{x}$ emissions from 1990 to 2020 based on an energy consumption scenario to illustrate the situation of the rapid increase in $\mathrm{NO}_{x}$ emissions in Asia. The early stage emission inventories including the Asian region had large inaccuracies because of the insufficient information on emission factors in this region, which were often based on information obtained from studies conducted in European or North American countries (Ma and van Aardenne, 2004). Several followup studies have been carried out to derive improved emission inventories for this region. Streets et al. (2003) constructed a comprehensive regional emission inventory with more species in support of the TRACE-P (Transport and Chemical Evolution over the Pacific) mission for Asia in 2000. However, Wang et al. (2004) concluded that the $\mathrm{NO}_{x}$ emissions of the TRACE-P inventory are largely underestimated, especially for China, compared to the emissions constrained by measurements from ground stations and aircrafts. Zhang et al. (2009) developed an updated Asian inven- tory for the INTEX-B (Intercontinental Chemical Transport Experiment-Phase B) mission in 2006, which was based on the TRACE-P inventory but with refined temporal and spatial resolution. In 2007, a long-term Asian inventory REAS (Regional Emission inventory in ASia) was developed by Ohara et al. (2007) to analyse the trend of emissions. Kurokawa et al. (2013) updated the REAS inventory to a higher spatial and temporal resolution. Lee et al. (2011) built the first version of the South Korean national emission inventory CAPSS (Clean Air Policy Support System) using more detailed local information for emission activities and factors. Tsinghua University developed the Chinese inventory MEIC (Multiresolution Emission Inventory for China) based on earlier work of Zhang et al. (2009) (http://www.meicmodel.org). Recently, Li et al. (2017) constructed the new Asian inventory MIX by combining different regional and national inventories including REAS version 2.1, CAPSS, and MEIC. Zhao et al. (2011) concluded based on Monte Carlo simulations that the uncertainties of bottom-up emissions of $\mathrm{NO}_{x}$ are about -13 to $37 \%$ in China. The major uncertainties are due to oversimplified source classifications and roughly estimated emission factors. The main anthropogenic emissions of $\mathrm{NO}_{x}$ in China are from transport and coal-fired power plants (Liu et al., 2015; Saikawa et al., 2017; Li et al., 2017). Because of the rapid implementation of new technologies and air quality control regulations for power plants and vehicles in China, their emission factors and activities are also changing with time, which makes the bottom-up emission estimates more uncertain (Zheng et al., 2014; Liu et al., 2015).

Satellite observations of atmospheric species can be used to closely monitor changes in emissions, such as the trend, seasonality, and diurnal cycles of emissions (Streets et al., 2013). For example, with satellites it was observed that $\mathrm{NO}_{x}$ emissions in China started to decrease after $2011(\mathrm{Gu}$ et al., 2013; de Foy et al., 2016; Krotkov et al., 2016; van der A et al., 2017) as a result of the national regulations for denitrification equipment at power plants. Mijling and van der A (2012) for the first time derived high-resolution $\left(0.25^{\circ} \times 0.25^{\circ}\right)$ emissions over East Asia from satellites using an advanced inverse method called DECSO (Daily Emission estimates Constrained by Satellite Observations) based on an extended Kalman filter. Ding et al. (2015) demonstrated that this approach is able to detect the monthly change of $\mathrm{NO}_{x}$ emissions due to air quality regulations on a city level. Miyazaki et al. (2012) derived the first global $\mathrm{NO}_{x}$ emission estimates using an inversion technique based on an ensemble Kalman filter and improved this method to constrain $\mathrm{NO}_{x}$ emissions by using satellite observations of multiple species (Miyazaki and Eskes, 2013; Miyazaki et al., 2017). This method is referred to as EnKF in this paper.

All emission inventories, both bottom-up and satellitederived, are facing the same challenge of validation since it is difficult to directly measure emissions on the ground on such large scales. A common way to validate emission inventories is using them in a chemical transport model to simulate 

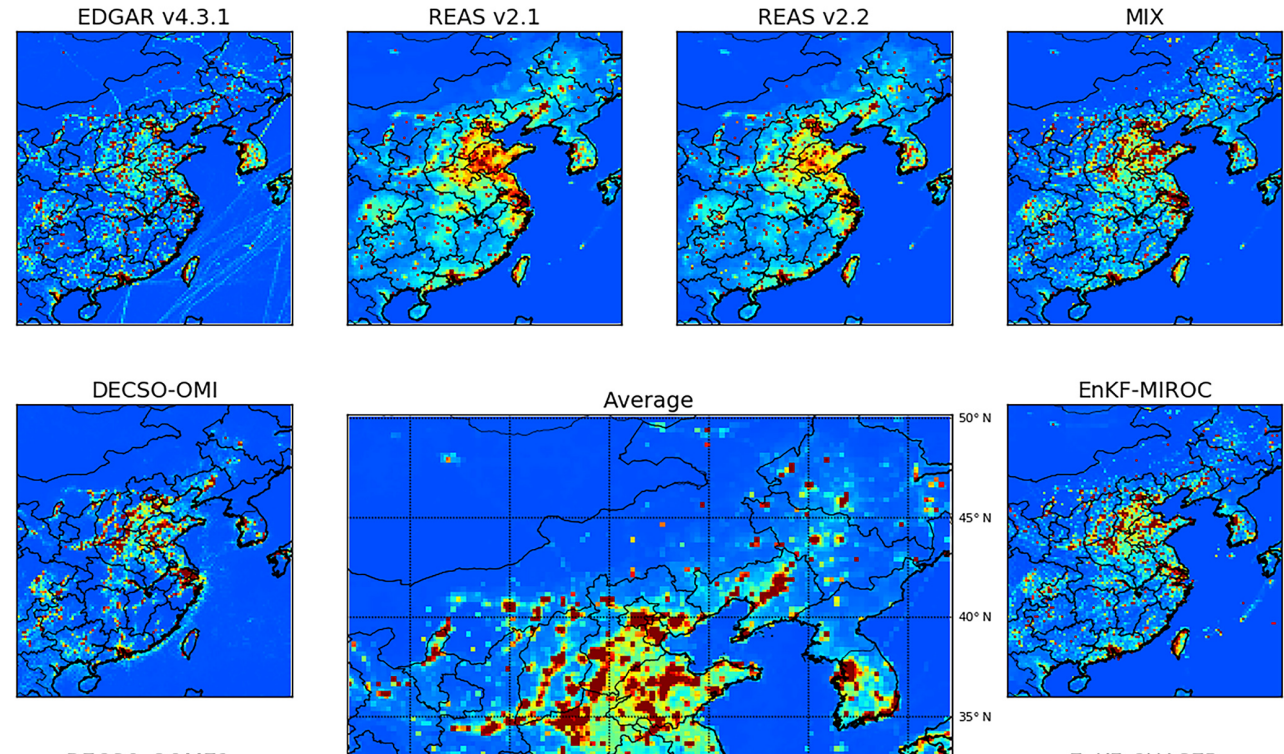

EnKF-MIROC
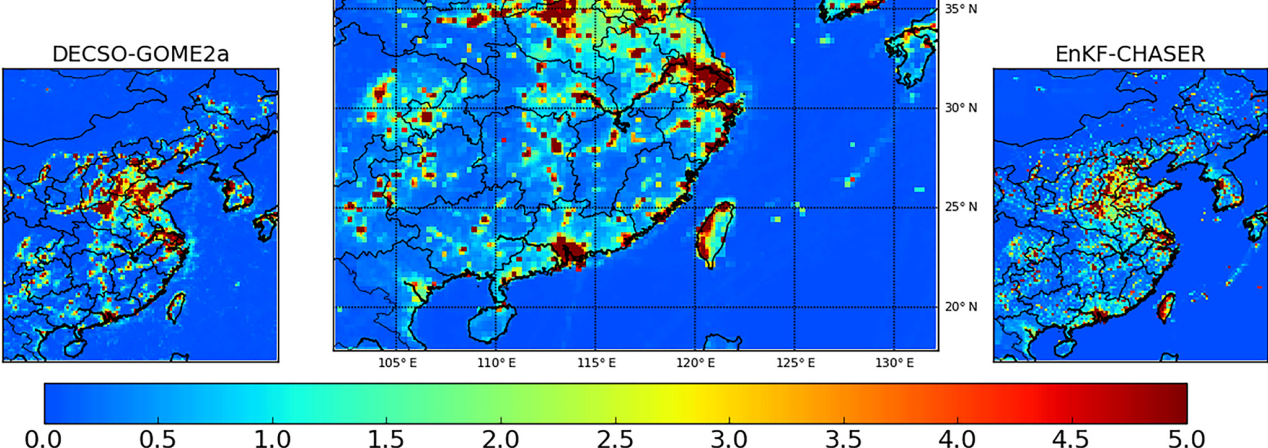

$$
\mathrm{Mg} \mathrm{N} \mathrm{km}^{-2} \mathrm{yr}^{-1}
$$

Figure 1. $\mathrm{NO}_{x}$ emissions over East Asia of all inventories in this study and their average in 2008. The averaged emissions over land are the mean of all emission inventories. Over the ocean the emissions are the average of DECSO-OMI, DECSO-GOME2, REAS v2.2 and EDGAR v4.3.1.

$\mathrm{NO}_{2}$ column concentrations and compare these with in situ or satellite observations. In this way, however, the validations are highly related to the model performance, which may result in inconsistent conclusions (Zhao et al., 2011).

In this study, we compare the satellite-derived inventories from DECSO and EnKF with a comprehensive collection of regional bottom-up inventories for East Asia: REAS v2.1 and an interim version of 2.2, MEIC, CAPSS and EDGAR v4.3.1 (Emissions Database for Global Atmospheric Research). The global HTAP v2 is not used because in our domain it is identical to MIX, which includes REAS, MEIC, and CAPSS. To evaluate the effect of the satellite instrument, we compare two emission datasets from DECSO applied to GOME2 and OMI observations. To examine the effect of the forecast model performance in the inversion, we compare two emission datasets from EnKF using different CTMs. The intercomparison of nine emission inventories is presented for the time period $2000-2015$ for East Asia on a $0.25^{\circ} \times 0.25^{\circ}$. Figure 1 shows the emission maps in 2008 of all inventories used in this study, including an average of emissions from all these inventories over the selected domain $\left(102-132^{\circ} \mathrm{E}\right.$, $\left.18-50^{\circ} \mathrm{N}\right)$. The description of all emission inventories used in this study will be presented in Sect. 2. Section 3 shows the difference of the spatial and temporal distribution among the nine inventories. The uncertainties of the inventories are discussed in Sect. 4.

\section{Emission inventories}

\subsection{Bottom-up inventories}

\subsubsection{EDGAR}

The Emissions Database for Global Atmospheric Research (EDGAR) (Janssens-Maenhout et al., 2013) is a global bottom-up emission inventory using consistent methodology allowing straightforward implementation of scenario assumptions. Emission calculations of the latest version, v4.3.1, are based on information of international energy balances of IEA (IEA, 2014a, b) and agricultural statistics of 
FAO (2012)and other national or regional statistical information. EDGAR classifies emissions into 12 source sectors: energy, combustion in manufacturing industry, industrial processes and product use, oil production and refining, fossil fuel fires, road transport, non-road ground transport, aviation, shipping, agricultural waste burning, residential and others. It provides global gridded maps of sector specific and historical emission data from 1970 to 2010 (monthly for 2010) with a high spatial resolution of $0.1^{\circ} \times 0.1^{\circ}$. A detailed description of EDGAR v4.3.1 can be found in Crippa et al. (2016). In this study, we use the yearly emissions of $\mathrm{NO}_{x}$ from 2000 to 2010 integrated to a resolution of $0.25^{\circ} \times 0.25^{\circ}$ on our study domain.

\subsubsection{REAS}

The Regional Emission inventory in ASia (REAS) v2.1 (Kurokawa et al., 2013) provides $\mathrm{NO}_{x}$ emission from 2000 to 2008 at a $0.25^{\circ} \times 0.25^{\circ}$ horizontal resolution. REAS v2.1 is based on the previous version REAS v1.1 with updates of activity data and parameters as well as an improvement of temporal and spatial resolution. It enlarges the domain by adding central Asia and the Asian part of Russia. REAS v1.1 was developed by Ohara et al. (2007) based on the methods described in Streets et al. (2003), which provided historical and future projected emissions from 1980 to 2020 at a $0.5^{\circ} \times 0.5^{\circ}$ resolution for East, Southeast and South Asia. REAS contains calculated $\mathrm{NO}_{x}$ emissions for the source sector of energy, industry, transport, domestic, agricultural activities and soil. We use $\mathrm{NO}_{x}$ emission data of REAS v2.1 and an interim version of 2.2 (hereafter REAS v2.2 for convenience) of 2005 to 2010 to expand the time series of the current REAS inventory. REAS v2.1 includes shipping, aviation emissions that are taken from EDGAR v4.2. In REAS v2.2, soil emissions and all emissions over central and Russian Asia are not included.

\subsubsection{MEIC}

Tsinghua University in Beijing has developed the Multiresolution Emission Inventory for China (MEIC) model to generate an anthropogenic emission inventory for mainland China with a spatial resolution of $0.25^{\circ} . \mathrm{NO}_{x}$ emissions are presented in four sectors: energy, industry, transport and residential. The China coal-fired Power plant Emission Database (CPED) is used for the power plant sector. CPED includes the latest detailed information of emission factors, activity, locations, etc. and takes emission regulations into account as well (Liu et al., 2015). In the transportation sector, vehicle population and emission factors at county level are combined with a digital road map, vehicle and road type to derive high-resolution on-road transportation emissions (Zheng et al., 2014). More detailed information of MEIC is described in $\mathrm{He}$ (2012) and $\mathrm{Li}$ et al. (2017). We use monthly $\mathrm{NO}_{x}$ emissions of MEIC v1.2 from 2007 to 2012.

\subsubsection{CAPSS}

The Clean Air Policy Support System (CAPSS) is a Korean emissions inventory system which provides annual air pollutant emissions with a spatial resolution of $1 \mathrm{~km}$ in South Korea as described by Lee et al. (2011). For CAPSS, point source emissions are derived from both emission factors and activity data. The emission source sectors are classified into 12 sectors, which are the same as for EDGAR. The latitude and longitude are given for each point source to indicate their location. Area emissions are downscaled by using cityprovince-level activity data including a spatial allocation index database. On-road mobile emissions are calculated by using VKT (vehicle kilometres travelled) and spatially allocated by using traffic volume information for each road. In this study, we use CAPSS $\mathrm{NO}_{x}$ emissions from 2001 to 2013 and re-grid the data to a resolution of $0.25^{\circ} \times 0.25^{\circ}$.

\subsubsection{MIX}

MIX is a mosaic Asian anthropogenic emission inventory developed by the Model Inter-Comparison Study for Asia (MICS-Asia) and the Task Force on Hemispheric Transport of Air Pollution (TF HTAP) projects (Li et al., 2017). Five emission inventories of different regions are combined in MIX by normalizing source categories, species, and spatial and temporal resolution of each inventory and provides data in a consistent format. The five inventories are REAS v2.1, MEIC v1.0, $\mathrm{PK}^{-\mathrm{NH}_{3}}$ (a high-resolution $\mathrm{NH}_{3}$ emission inventory developed by Peking University), ANL-India (an Indian emission inventory developed by Argonne National Laboratory) and CAPSS. The spatial resolution of MIX is $0.25^{\circ} \times 0.25^{\circ}$. We use $\mathrm{NO}_{x}$ emissions from MIX in 2008 to represent both MEIC and CAPSS for the spatial comparison in this study.

\subsection{Satellite-derived inventories}

\subsubsection{DECSO}

Daily Emission estimates Constrained by Satellite Observations (DECSO) is an inverse modelling method to update daily emissions of $\mathrm{NO}_{x}$ based on an extend Kalman filter (Mijling et al., 2013). $\mathrm{NO}_{x}$ emissions are constrained by combining simulated $\mathrm{NO}_{2}$ column concentrations of a regional CTM with satellite observations. The essential part in the inverse calculation is deriving the sensitivity of the $\mathrm{NO}_{2}$ column concentrations on $\mathrm{NO}_{x}$ emissions. A simplified isobaric surface 2-D trajectory analysis is used to take into account the transport of $\mathrm{NO}_{2}$ from the source for a fast sensitivity calculation. In the Kalman filter, the emissions are assumed to follow a persistent model, which expresses that emissions of tomorrow will be equal to emissions of today. The Eulerian regional offline CTM CHIMERE v2013 (Menut et al., 2013) is used to obtain simulated $\mathrm{NO}_{2}$ concentrations based on a priori emissions. Note that emissions 
derived with DECSO become independent from the a priori emissions after a spin-up time of about 3 months. CHIMERE is implemented at a $0.25^{\circ} \times 0.25^{\circ}$ horizontal resolution of the region for East Asia $\left(102-120^{\circ} \mathrm{E}, 18-50^{\circ} \mathrm{N}\right)$ driven by the European Centre for Medium-Range Weather (ECWMF) operational forecast. The model is set up with eight vertical layers from the surface to $500 \mathrm{hPa}$. The CHIMERE-simulated columns are extended from $500 \mathrm{hPa}$ to the tropopause with a climatological partial column (2003-2008 average) simulated by the global CTM TM5 for comparison with satellite observed tropospheric columns. The updates of emissions are related to the difference in $\mathrm{NO}_{2}$ between the CTM simulation and satellite observations. A detailed description of DECSO can be found in Mijling et al. (2013), while the latest improvements are described in Ding et al. (2015, 2017). $\mathrm{NO}_{x}$ emissions detected with DECSO are regarded as total surface emissions. Note that the algorithm is not able to capture the emission with temporary changes less than 1 day.

DECSO v5 has been applied to observations from OMI (Ozone Monitoring Instrument) and GOME-2 (Global Ozone Monitoring Experiment-2). OMI is a Dutch-Finnish instrument aboard NASA's EOS-Aura satellite (Levelt et al., 2006). The pixel size is $24 \mathrm{~km} \times 13 \mathrm{~km}$ at nadir and increases to about $150 \mathrm{~km} \times 28 \mathrm{~km}$ at the edge of the swath. The overpass time of OMI at the equator is about 13:30 local time. We use the tropospheric $\mathrm{NO}_{2}$ column data of the Dutch OMI $\mathrm{NO}_{2}$ retrieval (DOMINO) algorithm version 2 (Boersma et al., 2011). GOME-2 is aboard the Sunsynchronous satellite MetOp-A with a local overpass time of around 09:30. The pixel size of the observation was $80 \mathrm{~km} \times 40 \mathrm{~km}$ until 15 July 2013. Afterwards, the scan width of the orbit is halved and the pixel size is changed to $40 \mathrm{~km} \times 40 \mathrm{~km}$. Tropospheric $\mathrm{NO}_{2}$ columns of GOME- 2 are also retrieved with the algorithm DOMINO v2.

Observations are selected with a surface albedo lower than $20 \%$ and a cloud radiance fraction lower than $70 \%$. The observations with clouds below $800 \mathrm{hPa}$ are excluded. For OMI data, the pixels affected by the so-called row anomaly (KNMI, 2012) and the four pixels at each side of the swath are filtered out as well. The filter criteria are based on the analyses of Ding et al. $(2015,2017)$ to reduce the number of low-quality retrievals. The monthly DECSO v5 dataset used in this study is based on OMI satellite observations for the period of 2007-2015 (DECSO-OMI) and based on GOME-2 satellite observations for the period of 2008-2015 (DECSOGOME2a). The data are available at www.globemission.eu.

\subsubsection{Ensemble Kalman filter (EnKF)}

Miyazaki et al. (2012) developed a data assimilation system to estimate global $\mathrm{NO}_{x}$ emissions based on an ensemble Kalman filter technique, which combines satellite observations with a global CTM. In this paper, we refer to this method as EnKF. In this approach, surface $\mathrm{NO}_{x}$ emissions are included in the state vector together with other variables such as lightning $\mathrm{NO}_{x}$ sources and $\mathrm{NO}_{2}$ concentrations. The dependence of $\mathrm{NO}_{2}$ concentrations on $\mathrm{NO}_{x}$ emissions (including complicated chemistry and transport) is taken into account by using a background error covariance estimated from ensemble CTM forecasts. Miyazaki and Eskes (2013) demonstrated improved $\mathrm{NO}_{x}$ emission estimates by assimilating multiple species (including $\mathrm{O}_{3}$ from TES and MLS, $\mathrm{HNO}_{3}$ from MLS, CO from MOPITT). In this approach, the assimilation of non- $\mathrm{NO}_{2}$ measurements (e.g. $\mathrm{O}_{3}$ and $\mathrm{CO})$ influences largely the concentration and chemical lifetime of $\mathrm{NO}_{x}$ and thus the surface $\mathrm{NO}_{x}$ emission estimates. Miyazaki et al. (2017) updated the EnKF system to combine $\mathrm{NO}_{2}$ retrievals from OMI, GOME2 and SCIAMACHY together with the non- $\mathrm{NO}_{2}$ measurements to optimize the diurnal emission variability. SCIAMACHY (aboard ENVISAT) (Bovensmann et al., 1999) operated from 2002 until 2012 with a local overpass time of 10:00 and global coverage every 6 days. The tropospheric $\mathrm{NO}_{2}$ columns are retrieved with DOMINO v2 (Boersma et al., 2004). Observations with a cloud radiance reflectance lower than $50 \%$ were used. Two emission datasets are derived using this approach with two different global CTMs: CHASER (Sudo et al., 2002) and MIROC-Chem (Watanabe et al., 2011) (referred to as EnKFCHASER and EnKF-MIROC, respectively) for 2005-2015.

CHASER is coupled with an atmospheric general circulation model, CCSR/NIES/FRCGC AGCM v5.7b at a horizontal resolution of $2.8^{\circ}$ (T42) and 32 vertical levels on the sigma vertical coordinate system from the surface to $4 \mathrm{hPa}$ (Miyazaki and Eskes, 2013). The AGCM fields were nudged toward NCEP/DOE-II reanalysis (Kanamitsu et al., 2002). The MIROC-Chem model (Watanabe et al., 2011) was developed based on CHASER, with many updates on the tropospheric chemistry and including stratospheric chemistry. MIROC-Chem is coupled to the atmospheric general circulation model MIROC-AGCM v4, at 2.8 (T42) horizontal resolution, and it uses the hybrid terrain-following pressure vertical coordinate system with 32 vertical levels from the surface to $4.4 \mathrm{hPa}$ (Miyazaki et al., 2017). The MIROC-AGCM fields were nudged towards the 6-hourly ERA-Interim (Dee et al., 2011) reanalysis.

In both calculations, the a priori $\mathrm{NO}_{x}$ emissions are obtained from EDGAR v4.2 for anthropogenic emissions, GFED v3.2 (van der Werf et al., 2010) for biomass burning emissions and GEIA (Yienger and Levy, 1995) for soil emissions. For the comparison, the monthly emissions at $2.8^{\circ}$ resolution from EnKF-CHASER and EnKF-MIROC are redistributed to a horizontal resolution of $0.25^{\circ} \times 0.25^{\circ}$ based on emission distributions of the a priori inventory MIX. Note that the shipping emissions near the coast areas are added to land since they are not included in MIX. This could lead to overestimation of emissions over land near busy shipping lanes. 


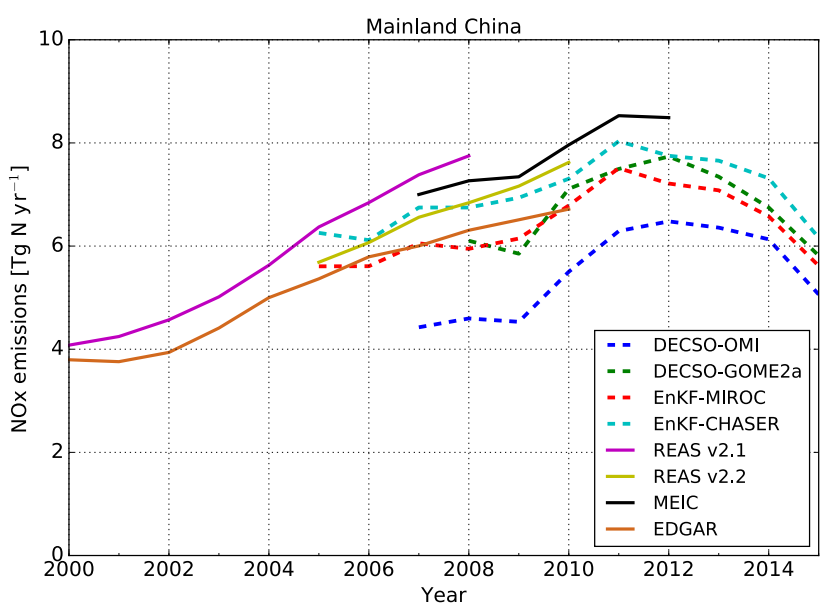

Figure 2. Annual $\mathrm{NO}_{x}$ emissions from eight emission inventories over mainland China in the selected domain (Fig. 1).

\section{Intercomparison of $\mathrm{NO}_{x}$ emissions}

\subsection{Temporal evaluation}

\subsubsection{Time series analysis}

Figure 2 shows the comparison of all emission inventories as a function of time over mainland China (in this paper limited to the study domain shown in Fig. 1) for the period 20002015. The time series of the annual total emissions show a large variation among the inventories. The bottom-up inventories use similar approaches, but the statistical data and assumptions on the penetration and specification of the present technologies used for their calculations are different and this explains the diversity among the bottom-up inventories. The differences among the satellite-derived emission inventories are caused by different inversion techniques, satellite observations and CTMs. The emissions derived by DECSO with OMI observations show a large discrepancy with the other inventories. Over mainland China (Fig. 2), all inventories follow a similar trend but with large biases. The $\mathrm{NO}_{x}$ emissions dramatically increase since 2000 and start to decrease around 2011. All satellite-derived inventories show a decrease in 2015 of at least $20 \%$ compared to 2014 . The average annual total emissions of 2008 (the only year included in all inventories) are about $5 \pm 1 \mathrm{Tg} \mathrm{Nyr}^{-1}$ for mainland China. REAS v2.1 presents the highest value of $7.3 \mathrm{Tg} \mathrm{N} \mathrm{yr}^{-1}$, while DECSO-OMI shows the lowest value of $4.3 \mathrm{Tg} \mathrm{Nyr}^{-1}$. The standard deviation of the emissions is about $20 \%$. For comparison, Li et al. (2017) reported typical uncertainties of 31$37 \%$ for bottom-up inventories over China.

Figure 3 shows the comparison of the temporal variation relative to the emissions in 2008. REAS v2.1 and v2.2 and EDGAR v4.3.1 show a continuous increase from 2000 to 2010 with an annual increase rate of about $8 \%$ on average. $\mathrm{NO}_{x}$ emissions of China in 2010 are almost doubled com-

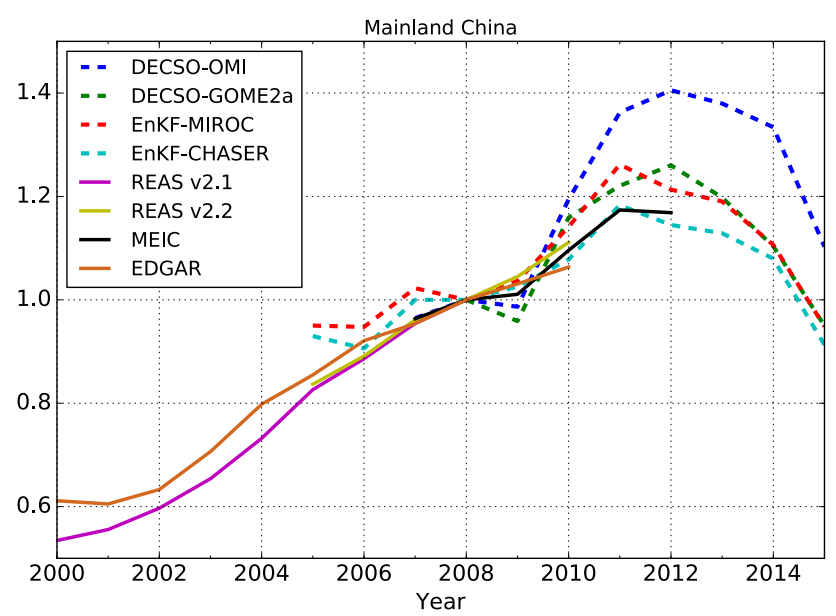

Figure 3. Normalized annual $\mathrm{NO}_{x}$ emissions from eight emission inventories over mainland China in the selected domain (see Fig. 1). The time series are normalized to their value in 2008 .

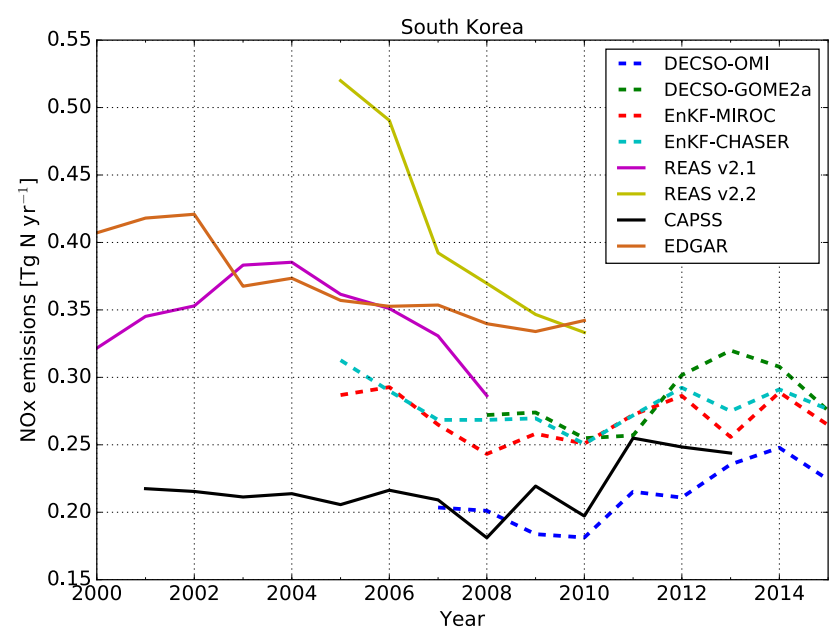

Figure 4. Annual $\mathrm{NO}_{x}$ emissions from eight inventories over South Korea.

pared to emissions in 2000. The change rates derived with two EnKF emissions are lower than for REAS and EDGAR between 2005 and 2010. MEIC and satellite-derived emissions show a slow change of $\mathrm{NO}_{x}$ emissions from 2007 to 2009 and a large increase in 2010 until 2011, which is consistent with satellite observations (Gu et al., 2013; de Foy et al., 2016; Krotkov et al., 2016), whereas REAS and EDGAR reveal a continuous increase during 2007-2010. The increase rate in 2011 of DECSO-OMI is about $10 \%$ higher than of the other inventories. From 2012 to 2015, the satellite-derived emissions show a decrease in total $\mathrm{NO}_{x}$ emissions over China by about $30 \%$. Nevertheless, the peak year is different between the satellite-based approaches. The DECSO inventories show a decrease starting in 2012, while the EnKF inventories reach their peak in 2011. 

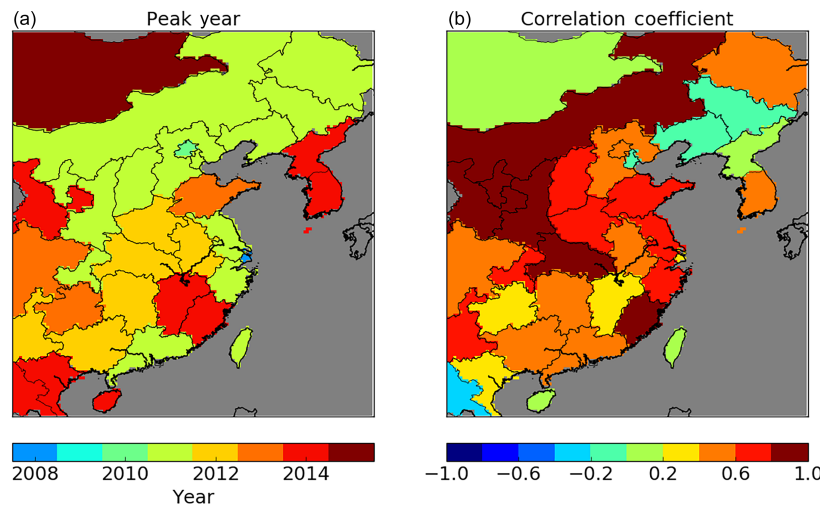

Figure 5. The peak year (a) of the average annual $\mathrm{NO}_{x}$ emissions from the four satellite-derived inventories (DECSO-OMI, DECSO-GOME2a, EnKF-CHASER and EnKF-MIROC) for various provinces and regions. (b) The map image shows the minimum temporal correlation coefficient of all combinations of the four emission datasets.

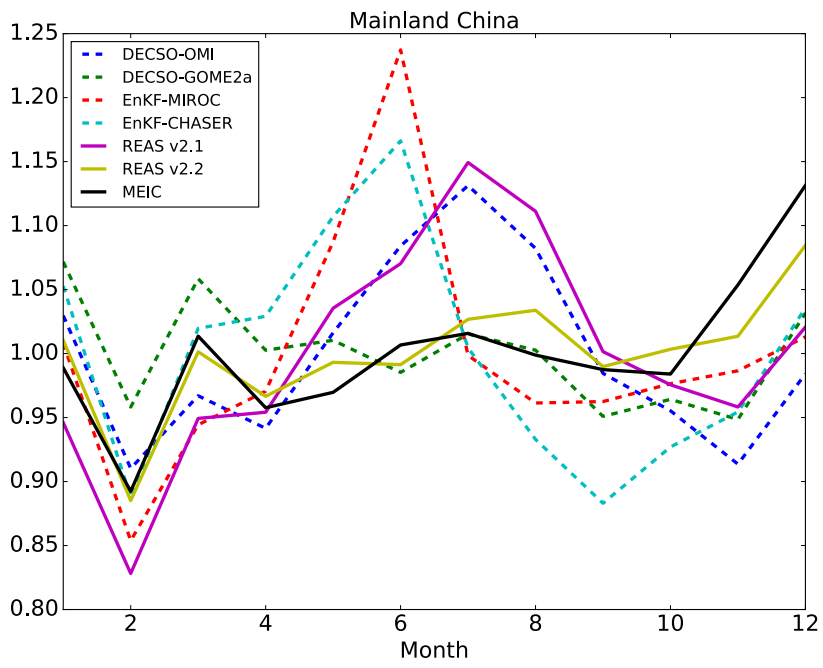

Figure 6. Monthly variability in $\mathrm{NO}_{x}$ emissions over mainland China in the selected domain (see Fig. 1).

Over a small domain, the discrepancies among the inventories are larger. As an example, Fig. 4 shows the comparison of the emission time series from eight inventories in South Korea. We see differences by a factor of up to 2 between the inventories in 2008 (the highest one is REAS v2.2 and the lowest one is CAPSS). The bottom-up inventories EDGAR and REAS show higher emissions than the satellite-derived emissions. The satellite-derived inventories are generally in closer agreement to the South Korean CAPSS than to the other bottom-up inventories. These results highlight the large differences in the emission trends over a small region like South Korea, even derived with a similar approach.

The satellite-based approaches can be used to make nearreal-time datasets and to extend the emission record over a longer period until 2015. Figure 5a displays the peak year of the averaged $\mathrm{NO}_{x}$ emissions from the four satellite-derived inventories. Beijing and Shanghai reach their peak years as early as 2010 and 2008, respectively. Most of the developed provinces reach maximum emissions in 2011 or 2012. In some less developed provinces, emissions were still growing until 2014. To analyse the correlation of the time series of the four satellite-derived inventories for each province, we calculate the temporal correlation coefficient $(R)$ from each combination of the four emission datasets. Figure $5 b$ shows the minimum correlation coefficient of all combinations. The satellite-derived emission inventories are in good agreement for most of the provinces, with a correlation coefficient higher than 0.6. The provinces with smaller areas often have lower $R$ values. This means that the uncertainties of $\mathrm{NO}_{x}$ emissions can be notably high on a small area or provincial level.

\subsubsection{Monthly variability}

We calculate the mean monthly emissions of each inventory for its own available time period and normalize them to get the general monthly variability. Figure 6 shows the monthly variability in total $\mathrm{NO}_{x}$ emissions for seven inventories over mainland China. MEIC, REAS v2.1 and DECSO-GOME2a show a relatively weak variability, while the other four inventories show a distinct summer peak. The EnKF inventories show a sharp peak in June. REAS v2.1 and DECSO-OMI reveal a peak in July. The summertime peak is probably introduced by enhanced biogenic (e.g. from soils) emissions. The summertime enhancement is considered to be better detected by the OMI afternoon measurements than the GOME2 morning measurements (Boersma et al., 2009) because they are generally maximized in the afternoon. The different representation of the summertime peak between the satellitederived inventories will be discussed in Sect. 4.4. It is notable that all inventories show that $\mathrm{NO}_{x}$ emissions are about $10 \%$ lower in February than in the surrounding months, which is due to the Chinese New Year (Ding et al., 2015). All inventories also show a peak in December, when heating and electricity consumption is usually high in China.

To study the temporal correlation of monthly different inventories, we use monthly emissions over mainland China of the common period (2008-2010, i.e. 36 months) for DECSO, EnKF, MEIC, and REAS v2.2. Table 1 shows the correlation coefficient of monthly total emissions from different inventories over mainland China from 2008 to 2010. The two DECSO inventories show a relatively good correlation with MEIC and REAS. The correlation coefficient between the two DECSO inventories is only 0.75 as a result of the different seasonality (see Fig. 6). This implies that the observed seasonality can be highly affected by the choice of satellite observations, reflecting differences in the local overpass time and pixel size. The two EnKF inventories based on the same observations but using different forecast mod- 
Table 1. Temporal correlation coefficient of the 36 pairs of monthly $\mathrm{NO}_{x}$ emissions over mainland China from 2008 to 2010 . The bold values indicate the relation between bottom-up and satellite-based inventories.

\begin{tabular}{lrrrrr}
\hline & REAS v2.2 & MEIC & EnKF-MIROC & EnKF-CHASER & DECSO-GOME2a \\
\hline DECSO-OMI & $\mathbf{0 . 7 2}$ & $\mathbf{0 . 6}$ & 0.52 & 0.45 & 0.75 \\
DECSO-GOME2a & $\mathbf{0 . 7 8}$ & $\mathbf{0 . 7 4}$ & 0.46 & 0.28 & 1 \\
EnKF-CHASER & $\mathbf{0 . 4 3}$ & $\mathbf{0 . 4 3}$ & 0.65 & 1 & - \\
EnKF-MIROC & $\mathbf{0 . 4 6}$ & $\mathbf{0 . 4 3}$ & 1 & - & - \\
MEIC & 0.91 & 1 & - & - & - \\
\hline
\end{tabular}

Table 2. Spatial correlation coefficients of annual $\mathrm{NO}_{x}$ emissions in 2008 over land on a provincial level in China and other regions outside China. (The total number of provinces and regions is 33, i.e. 29 Chinese provinces, South Korea, North Korea, and parts of Mongolia (83\%) and Vietnam (43\%); see Fig. 1. The study domain only covers part of the provinces Heilongjiang (74\%), Inner Mongolia (83\%) and Yunnan $(36 \%)$.) The bold values indicate the relation between bottom-up and satellite-based inventories

\begin{tabular}{lrrrrrrr}
\hline & EDGAR v4.3.1 & REAS v2.1 & REAS v2.2 & MEIC & EnKF-MIROC & EnKF-CHASER & DECSO-GOME2a \\
\hline DECSO-OMI & $\mathbf{0 . 8 4}$ & $\mathbf{0 . 9 0}$ & $\mathbf{0 . 9 1}$ & $\mathbf{0 . 9 2}$ & 0.96 & 0.95 & 0.98 \\
DECSO-GOME2a & $\mathbf{0 . 8 5}$ & $\mathbf{0 . 9 2}$ & $\mathbf{0 . 9 4}$ & $\mathbf{0 . 9 5}$ & 0.96 & 1 \\
EnKF-CHASER & $\mathbf{0 . 8 8}$ & $\mathbf{0 . 9 2}$ & $\mathbf{0 . 9 3}$ & $\mathbf{0 . 9 5}$ & $\mathbf{0 5}$ & -96 & - \\
EnKF-MIROC & $\mathbf{0 . 8 8}$ & $\mathbf{0 . 9 4}$ & $\mathbf{0 . 9 5}$ & $\mathbf{0 . 9 5}$ & 1 & - & - \\
MEIC & 0.89 & 0.99 & 0.98 & 1 & - & - \\
REAS v2.2 & 0.90 & 0.99 & 1 & - & - & - \\
REAS v2.1 & 0.88 & 1 & - & - & - & - \\
EDGAR v4.3.1 & 1 & - & - & - & - & - \\
\hline
\end{tabular}

els show a strong correlation. However, for most cases on a provincial or a small regional level, no significant correlation of monthly variability from different approaches can be found (not shown). Due to the coarse resolution of the EnKF emission estimates (i.e. $2.8^{\circ}$ ), the seasonality can be strongly mixed up between urban and rural areas within a coarse model grid. The uncertainty in temporal variability in $\mathrm{NO}_{x}$ emissions becomes larger with decreasing spatial scale of emissions, especially where surface types are inhomogeneous.

\subsection{Spatial distribution}

In this section, we choose the year 2008 to compare the bias and spatial distribution, since it is the only year that is contained by all inventories. Because DECSO inventories have a grid that is half a grid cell shifted compared to the other inventories, the comparison per grid cell could theoretically result in up to $40 \%$ discrepancy in correlation coefficients due to re-gridding. The calculated discrepancy decreases to less than $10 \%$ at a resolution of $1^{\circ}$ or more. For a fair comparison, we check the correspondence in spatial distribution on a provincial level. We calculate the correlation coefficient $(R)$ of each two inventories on a regional or provincial level (in total 33 regions including 29 Chinese provinces, South Korea, North Korea, and parts of Vietnam (43\%) and Mongolia (53\%), as shown by Fig. 1. Note that our domain covers only a part of the provinces Heilongjiang (74\%), Inner Mongolia $(83 \%)$, Sichuan $(51 \%)$ and Yunnan $(36 \%)$. The comparison result is summarized in Table 2. We use the MIX inventory for 2008 to represent both MEIC and CAPSS depending on the region of interest, since MIX covers the whole domain. All correlation coefficients are above 0.8 , which means that the spatial distribution on a regional or provincial level have a good agreement among all inventories. The emission correlations are higher when the emissions are derived with similar methods. Both DECSO inventories have the best correlation with the EnKF inventories, with $R$ values around 0.95 . EnKF-CHASER and EnKF-MIROC show a similar spatial distribution. For the two EnKF inventories, the original $2.8^{\circ}$ resolution data were subsequently re-gridded to a finer resolution using the same fine-scale distribution. Both REAS inventories have very high correlations ( $R$ values are 0.98 and 0.99) with MIX since the same provincial activity data of China are used for calculating emissions in MIX and in REAS v2.1 (Kurokawa et al., 2013). The correlation between EDGAR v4.3.1 and other bottom-up emission inventories is relatively low $(R<0.85)$. EDGAR v4.3.1 uses the emission information from IEA (2014) statistics (before the coal statistics revision of China) and CARMA v3.1 for distribution while MIX and REAS are based on national statistics, which may lead to the discrepancy.

Both the bottom-up and satellite-derived inventories show large biases but their spatial distributions are similar on a provincial scale. To further examine the spatial distribution and biases, we combine the emissions in bins of $1^{\circ}$ latitude and compare the longitudinal total emissions over land in 


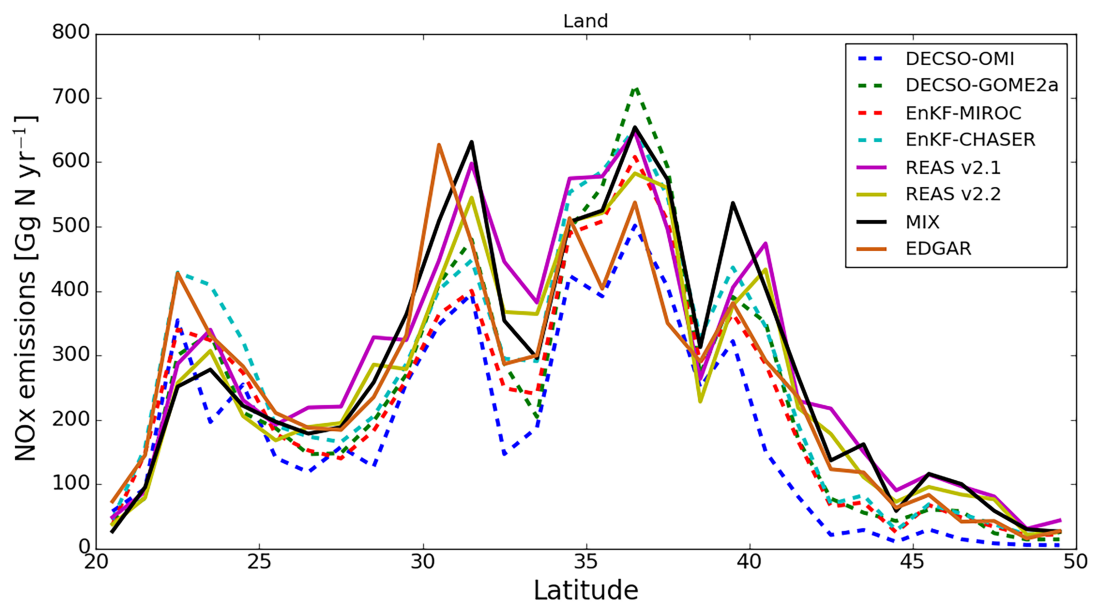

Figure 7. Latitudinal distribution of longitudinal total $\mathrm{NO}_{x}$ emissions over land. The emissions are summed over a $1^{\circ}$ longitudinal band above land.

the study domain. Figure 7 shows that all inventories have similar patterns over latitude but with large biases. The standard deviation averaged over the latitudes $\left(20-50^{\circ} \mathrm{N}\right)$ between all the inventories is $27 \%$. For areas, north of $40^{\circ} \mathrm{N}$, the satellite-derived emission inventories are lower than the bottom-up inventories. The relative standard deviation is also large (from 40 to $80 \%$ ) at high latitudes.

Note that the satellite-derived emissions are total surface emissions including anthropogenic, biogenic, and shipping emissions. MEIC and REAS v2.2 include only anthropogenic emissions. REAS v2.1 includes all emissions except for lightning by adding the aviation and international shipping emissions from EDGAR v4.2. These differences make the comparison inconsistent. To conduct consistent comparisons, we divide the domain into urban and rural areas based on land-use information and compare the emissions over each area. We use the land-use information at a resolution of $300 \mathrm{~m}$ from the GlobCover Land Cover (GCLC version 2.3) database, which is updated for the year 2009. We assume that an urban grid cell has more than $5 \%$ coverage of urban land. In GCLC, urban areas are defined as artificial surface and associated areas. If the grid cell is $100 \%$ covered by vegetation (including agricultural land, grass land, shrubs, forest) or barren land, it is regarded as a rural grid cell. We note that the anthropogenic emissions can still be the dominant source over the rural grid cells because urban areas (for example highways, small factories) can be smaller than the resolution of the GCLC data $(300 \mathrm{~m})$. Figure 8 shows the distribution of the urban and rural grid cells. The urban grid cells account for $4.5 \%$ of the total land area, while the rural grid cells cover about $41 \%$.

Figure 9 shows that the meridional distributions of emissions from all inventories over urban grid cells are in good agreement. Even though the urban grid cells are only about $4.5 \%$ of total land cover, they contribute to about $50 \%$ of the total emissions over the whole domain. The range of

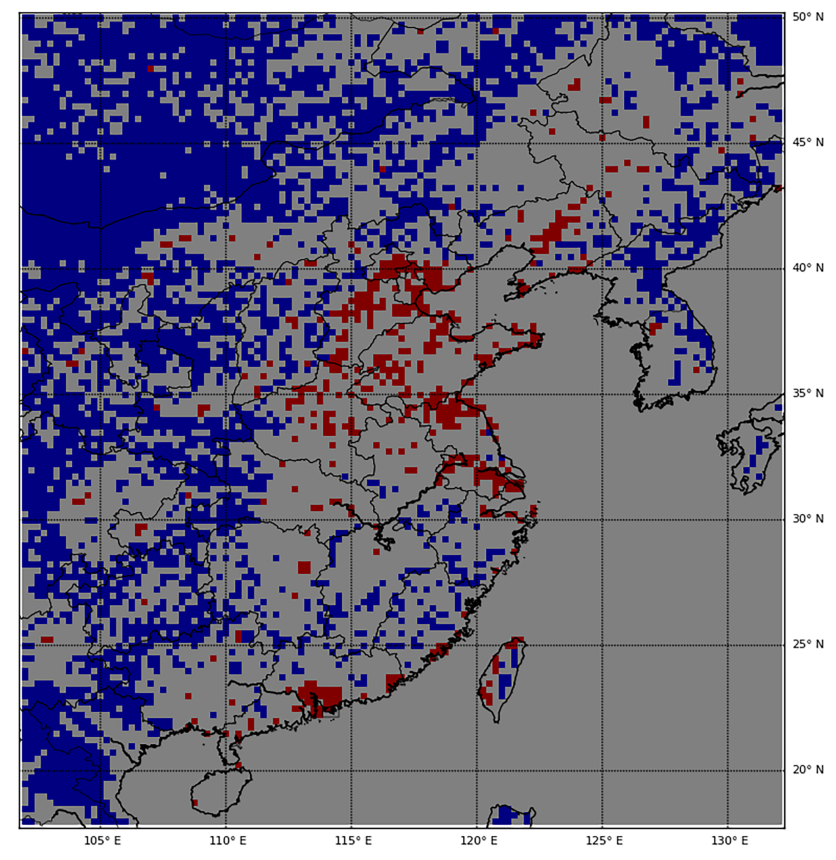

Figure 8. The distribution of urban grid cells (red) and rural grid cells (blue). Urban grid cells have an urban area (as defined in the GCLC database) larger than $5 \%$ of the grid cell. Rural grid cells are $100 \%$ covered by vegetation (including agricultural land, grass land, shrubs, forest) or barren land.

the total urban emissions is between about 2.0 (REAS v2.2) and 3.4 (MIX) $\mathrm{Gg} \mathrm{Nyr}^{-1}$. The standard deviation of the total urban emissions is about $19 \%$ of the ensemble mean. The urban emissions from DECSO-OMI is apparently lower than others above $40^{\circ} \mathrm{N}$. The urban emissions over the areas above $40^{\circ} \mathrm{N}$ contribute to only $6 \%$ to the total urban emissions over the whole domain in DECSO-OMI; the other inventories show larger contributions (about 10-15\%). 


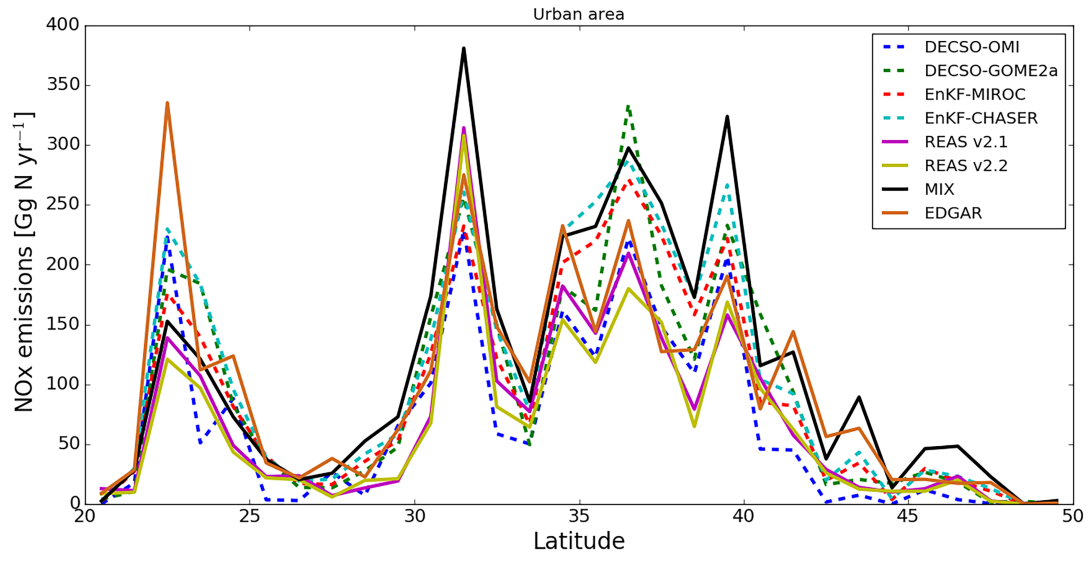

Figure 9. Latitudinal distribution of longitudinal total $\mathrm{NO}_{x}$ emissions over urban areas (the red cells in Fig. 8).

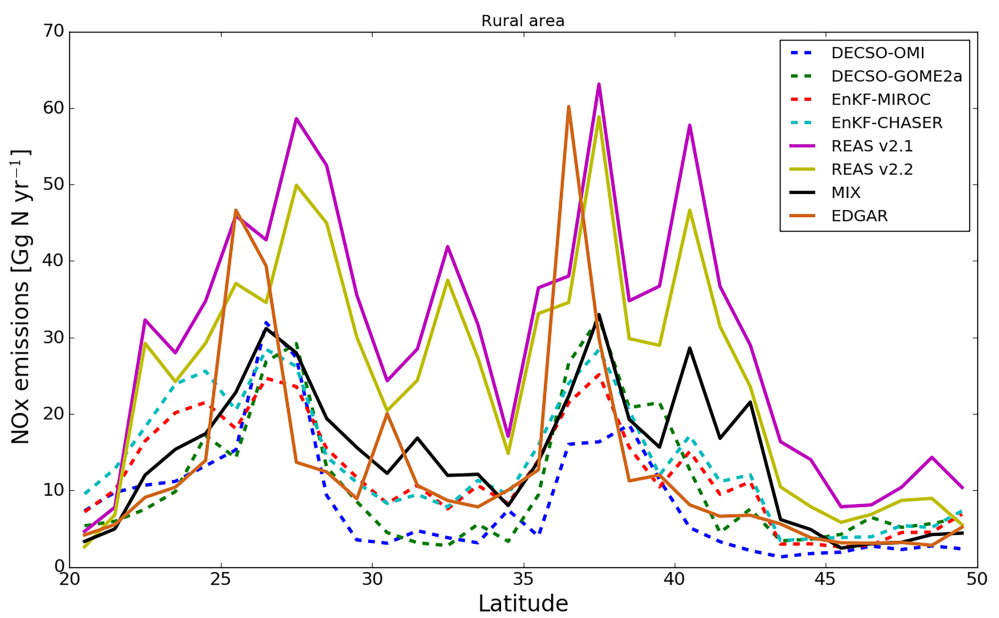

Figure 10. Same as Fig. 9, but for rural grid cells (the blue cells in Fig. 8).

Figure 10 shows that the emissions of all inventories over rural grid cells have wide spread along latitudes. The emissions over rural areas contribute to about $8 \%$ of the total emissions (254-900 $\mathrm{Gg} \mathrm{Nyr}^{-1}$ ) on average with a relative standard deviation of about $44 \%$ to the total emissions over the domain. EDGAR v4.3.1 emissions, which include biogenic (biofuel and biomass) emissions, are even lower than MIX and REAS v2.2, which include only anthropogenic emissions. The relative differences in emissions over rural areas are much larger than over urban areas, especially for the bottom-up inventories. These results suggest that large uncertainties over rural areas exist in the current bottom-up inventories. The mean differences are usually smaller for the satellite-derived inventories.

The seasonal cycle of the urban grid cells is quite similar to the one shown in Fig. 6 for all of mainland China. However, the seasonal cycle for the rural grid cells have a much stronger summer maximum for the inventories that include biogenic emissions. Tables 3 and 4 show the temporal correlation of monthly emissions among different in- ventories over urban and rural areas, respectively. The correlation coefficients are similar between the total emissions over land (Table 1) and over urban areas (Table 3). The two DECSO inventories have a high correlation over rural areas with REAS v2.1. A possible reason is that REAS v2.1 is the only bottom-up inventory in the comparison, which includes biogenic emissions. The EnKF datasets have low correlations with all bottom-up inventories probably due to its coarse horizontal resolution (see Sect. 3.1.2).

\section{Discussion}

\subsection{Temporal analyses}

Our intercomparison shows differences of about $10 \%$ in the time series over of the regional total emissions over mainland China. The peak year of the Chinese country-total emissions was 2011 in the EnKF and MEIC inventories, which is consistent with the results of Liu et al. (2016). Irie et al. (2016) showed that $\mathrm{NO}_{2}$ column concentrations derived 
Table 3. Temporal correlation coefficient of the 12 pairs of monthly total $\mathrm{NO}_{x}$ emissions over urban areas in the common year 2008 . The bold values indicate the relation between bottom-up and satellite-based inventories.

\begin{tabular}{lrrrrrr}
\hline & REAS v2.1 & REAS v2.2 & MIX & EnKF-MIROC & EnKF-CHASER & DECSO-GOME2a \\
\hline DECSO-OMI & $\mathbf{0 . 7 3}$ & $\mathbf{0 . 6 1}$ & $\mathbf{0 . 3 4}$ & 0.5 & 0.22 & 0.69 \\
DECSO-GOME2a & $\mathbf{0 . 5 3}$ & $\mathbf{0 . 6 7}$ & $\mathbf{0 . 4 8}$ & 0.72 & -0.04 & - \\
EnKF-CHASER & $\mathbf{0 . 2 8}$ & $\mathbf{0 . 2 1}$ & $\mathbf{0 . 4 7}$ & 0.21 & - & - \\
EnKF-MIROC & $\mathbf{0 . 1 1}$ & $\mathbf{0 . 2 4}$ & $\mathbf{0 . 2 5}$ & - & - & - \\
MIX & 0.72 & 0.83 & - & - & - & - \\
REAS v2.2 & 0.93 & - & - & - & - & - \\
\hline
\end{tabular}

Table 4. Same as Table 3, but for rural areas in 2008.

\begin{tabular}{lrrrrrr}
\hline & REAS v2.1 & REAS v2.2 & MIX & EnKF-MIROC & EnKF-CHASER & DECSO-GOME2a \\
\hline DECSO-OMI & $\mathbf{0 . 8 8}$ & $\mathbf{0 . 1 7}$ & $\mathbf{- 0 . 3 1}$ & 0.75 & 0.64 & 0.69 \\
DECSO-GOME2a & $\mathbf{0 . 8 8}$ & $\mathbf{0 . 3 3}$ & $\mathbf{- 0 . 2 1}$ & 0.12 & 0.20 & - \\
EnKF-CHASER & $\mathbf{0 . 4 6}$ & $\mathbf{- 0 . 0 2}$ & $\mathbf{- 0 . 1 2}$ & 0.75 & - & - \\
EnKF-MIROC & $\mathbf{0 . 4 7}$ & $\mathbf{0 . 2 0}$ & $\mathbf{0 . 0 4}$ & - & - & - \\
MIX & -0.13 & 0.80 & - & - & - & - \\
REAS v2.2 & 0.43 & - & - & - & - \\
\hline
\end{tabular}

from OMI observations started to decrease in 2011 in China. However, DECSO shows the peak year in 2012, which is consistent with the start of strict air quality regulations (van der A et al., 2017). Over South Korea, the local CAPSS inventory shows unchanging emissions until 2010 and increasing emissions since. REAS and EDGAR inventories show a strong decrease from 2005 to 2010 with large differences in the decrease rate. For bottom-up inventories, it is difficult to assume the correct timing of penetration of a given new technology. For instance, EDGAR assumes an immediate implementation of a new policy, e.g. low- $\mathrm{NO}_{x}$ burners, and so does not represent the real time of penetration of the new technology. All the satellite-based inventories show a decrease in 2015. This is different for concentrations derived from OMI measurements, which show a decrease from 2005 to 2013 and a slight increase in 2015 (Irie et al., 2016). Mijling et al. (2013) calculated that the $\mathrm{NO}_{2}$ transported from outside the country contributes to about $7 \%$ of the average $\mathrm{NO}_{2}$ columns over South Korea. Thus, the trend of $\mathrm{NO}_{2}$ column concentrations cannot always be used as an indication for the local emission because of influences of atmospheric transport. Miyazaki et al. (2017) indicated that an accurate emission trend requires an emission-concentration relationship that explicitly accounts for tropospheric chemistry and transport, which is included in advanced data assimilation techniques. This can cause significant differences between the bottom-up and satellite-derived emissions.

Three satellite-derived inventories (EnKF-CHASER, EnKF-MIROC and DECSO-OMI) and REAS v2.1 show a strong summer peak, which can be attributed to biogenic emissions in summer, such as enhanced soil emissions and emissions from biomass burning. REAS v2.1 includes biogenic emissions, while the other bottom-up inventories shown in Fig. 6 include only anthropogenic emissions. Zhao and Wang (2009) concluded that soil emissions are enhanced in summer and contribute to at least $14 \%$ of the total emissions in July in China. Soil emissions have a positive exponential relationship with soil temperature (Schindlbacher et al., 2004) and can be enhanced after precipitation over vegetation (Zörner et al., 2016), which could explain the seasonality in satellite-derived emissions in most parts of China. Also, emissions by biomass burning and crop burning are maximized in summer in China (Li et al., 2016; Zhang et al., 2016). Stavrakou et al. (2016) pointed out that the current biomass burning inventories are underestimating emissions by crop burning in northeast China. This can lead to significant differences in the emission seasonality between the bottom-up and satellite-derived emissions. The OMI satellite instrument with an overpass time in the afternoon will observe more $\mathrm{NO}_{2}$ from biomass burning than the GOME-2 instrument with its morning overpass time because of stronger biomass burning activities and high soil emissions in the afternoon (Boersma et al., 2008). This can explain why only the satellite-derived emission inventories based on OMI show a clear summer peak. The seasonality shown by DECSO-OMI and EnKF datasets is slightly different. One possible reason is the uncertainty in the $\mathrm{NO}_{x}$ chemical lifetime in the CTM. For instance, in summer, a too short lifetime can result in overestimation of emissions by the inversion method (Stavrakou et al., 2013). In addition, the EnKF data assimilation has frequent updates (every $120 \mathrm{~min}$ ), which may lead to overcorrection in the estimated emissions due to the persistent underestimation of $\mathrm{NO}_{x}$ concentrations by the CTM. 


\subsection{Spatial analyses}

All the inventories are in good agreement on the spatial distribution on a provincial level but with large biases. The differences in total annual emissions can increase to $100 \%$ for small spatial scales, which is in line with recent studies on regional emission inventories. For example, Saikawa et al. (2017) compared five bottom-up inventories on a provincial and national scale in China and concluded that more improvements are needed for provincial emissions. All satellitederived emissions are lower than that of bottom-up inventories at high latitudes (above $40^{\circ} \mathrm{N}$ ). This is probably due to negative bias of satellite observations at higher latitudes in East Asia (Ding et al., 2017; Lorente et al., 2017). Another reason can be the overestimation of $\mathrm{NO}_{x}$ lifetime in the CTM for high latitudes (Stavrakou et al., 2013), which could cause underestimation of the estimated emissions.

\subsection{Differences in the bottom-up emissions}

The differences in emission activity and emission factors of each emission sector can lead to large discrepancies in the bottom-up emission inventories. Saikawa et al. (2017) and Li et al. (2017) showed that large discrepancies in bottom-up emission estimates over China are mainly related to different statistical data and emission factors for the energy and transport sectors. All three inventories use different provincial statistics. The emission factors of power plants are lower in MEIC as compared to EDGAR and REAS. More power plants are included in MEIC, which uses the highresolution database CPED for China. REAS uses two other global databases, CARMA (Carbon Monitor for Action) and WEPP (World Electric Power Plants), while EDGAR uses downscaled IEA (International Energy Agency) statistics and CARMA v3.1 for the distribution. For the transport sector, each inventory has its own sub-categories to calculate the total emissions. MEIC includes only on-road vehicle emissions, while EDGAR and REAS give off-road emissions including emissions from ships and aircrafts. For vehicle emissions, MEIC uses the information from local statistics, but large uncertainties still exist in vehicle emission factors and activities. The selected vehicle emissions factors do not include spatial variability and the emissions activities are based on surveys conducted in only a few cities (Zheng et al., 2014). More details about the difference in bottom-up inventories can be found in $\mathrm{Li}$ et al. (2017). For South Korea, the $\mathrm{NO}_{x}$ emissions from CAPSS, using local data of emission factors and activities based on local measurements, are much lower than from other bottom-up inventories.

\subsection{Differences in the satellite-derived emissions}

The differences in the satellite-derived emissions are introduced by differences in inversion techniques, chemical transport models, and observations. For instance, errors in the simulated $\mathrm{NO}_{2}$ columns are largely influenced by the representation of lightning $\mathrm{NO}_{x}$ sources, especially in summer, and thus affect the quality of surface $\mathrm{NO}_{x}$ emissions estimates (Lin, 2012). In the EnKF analyses, lightning $\mathrm{NO}_{x}$ sources are simultaneously optimized using satellite measurements (Miyazaki et al., 2014), which can improve the surface emission estimation. In the DECSO algorithm, the $\mathrm{NO}_{2}$ concentrations above $500 \mathrm{hPa}$ were obtained from climatological data, and the lightning emissions are identified as surface emissions. The error in $\mathrm{NO}_{x}$ lifetime due to uncertainties in meteorological input and chemical processes also strongly affect the satellite-derived emission estimates (Lin et al., 2012; Stavrakou et al., 2013), which are differently represented in each model.

The emissions derived with DECSO using OMI are much lower than those from other satellite-derived inventories. The monthly variability is largely affected by changing the satellite observations in DECSO, which is attributed to the differences in the satellite overpass time (see Sect. 4.1) and uncertainty in modelled diurnal variations. $\mathrm{NO}_{2}$ columns observed by GOME2 are on average $20 \%$ higher than by OMI in the winter period (October-March), while they are up to $40 \%$ in the summer period (April-September) in 2014, reflecting stronger daytime photochemical sinks from oxidation by $\mathrm{OH}$ in summer (Boersma et al., 2009). Although the OMI and GOME-2 retrievals were produced using the same retrieval algorithm (Boersma et al., 2011), Wang et al. (2017) concluded that GOME2-A/B has a larger bias (about $30 \%$ ) than OMI satellite observations in Wuxi in China from 2011 to 2014. In addition, GOME-2 observes larger $\mathrm{NO}_{2}$ columns from the transport sector due to the morning rush hour (Wang et al., 2017), whereas OMI has better capability to detect emissions from biomass burning that usually at their maximum in the afternoon (Boersma et al., 2008; Miyazaki et al., 2017). To obtain better $\mathrm{NO}_{x}$ emission estimates from the satellite-based approach, it is useful to combine observations from multiple instruments obtained at different overpass time, as implemented in the EnKF inversions. Miyazaki et al. (2017) demonstrated that the application of a correction scheme for diurnal emission variability using multiple measurements (OMI, GOME-2, SCIAMACHY) is an important development in the emission estimates. Different from the DECSO algorithm, the EnKF emissions are obtained by assimilating multiple species, which provide constraints on various aspects of the tropospheric chemistry system to improve the $\mathrm{NO}_{x}$ emission estimates (Miyazaki and Eskes, 2013; Miyazaki et al., 2017). When comparing two $\mathrm{NO}_{x}$ emissions of EnKF-MIROC derived by assimilating multiple species and $\mathrm{NO}_{2}$ only, the average bias is about $5 \%$ for the annual total emissions over East Asia. This confirms that the emissions are strongly constrained by $\mathrm{NO}_{2}$ observations but are also modified by non- $\mathrm{NO}_{2}$ observations through their influences on the vertical profile and chemical lifetime of $\mathrm{NO}_{x}$.

EnKF-CHASER and EnKF-MIROC use the same data assimilation framework but different CTMs. Our comparisons 
reveal that the estimated emissions are largely sensitive to the forecast model. The bias between the two EnKF datasets is about $15 \%$ for the annual total emissions over the domain. The estimated emissions are generally higher in EnKFCHASER than in EnKF-MIROC, which could be attributed to the larger amount of $\mathrm{OH}$ and thus shorter $\mathrm{NO}_{x}$ chemical lifetime in EnKF-CHASER.

DECSO inventories show better temporal correlation with other inventories, especially over rural areas. Our analyses suggest that the estimated emissions are strongly influenced by the choice of model resolution $\left(0.25^{\circ}\right.$ in DECSO vs. $2.8^{\circ}$ in EnKF). Insufficient model resolution could cause artificial dilution and errors in simulating non-linear chemical feedback of $\mathrm{O}_{3}-\mathrm{HO}_{x}-\mathrm{NO}_{x}$ chemical system. Valin et al. (2011) also discussed that a sufficient horizontal resolution of model to accurately simulate the non-linear effect is related to the size of the emission source ( $4 \mathrm{~km}$ for a small source to $48 \mathrm{~km}$ for a large city). High-resolution inversion is considered to be essential to improve the emission estimates at small scales and to derive better temporal changes over different types of areas.

\section{Conclusions and recommendations}

To investigate the uncertainties in $\mathrm{NO}_{x}$ emission estimates over East Asia, we compared nine $\mathrm{NO}_{x}$ emission inventories from satellite-derived and bottom-up approaches over East Asia. The bottom-up inventories are obtained from a global inventory (EDGAR v4.3.1), regional inventories over Asia (REAS v2.1 and an interim version of 2.2), and national inventories of China (MEIC) and South Korea (CAPSS). The four satellite-derived inventories were derived with different versions of DECSO and EnKF. DECSO-OMI and DECSO-GOME2a are based on an extended Kalman filter using observations from OMI and GOME-2, respectively. EnKF-CHASER and EnKF-MIROC are based on an ensemble Kalman filter applied to multiple- $\mathrm{NO}_{2}$ and multiplespecies measurements using two different CTMs. The intercomparison of all inventories shows good agreement in $\mathrm{NO}_{x}$ emissions over mainland China with an average bias of about $20 \%$ for yearly emissions. All the inventories reveal common variability such as a typical emission reduction of $10 \%$ during the Chinese New Year and a sharp peak in December. All the inventories show good agreement in spatial distribution on a provincial level $(R>0.8)$. However, biases in $\mathrm{NO}_{x}$ emissions and uncertainties in temporal (both yearly and monthly) variability become quickly higher when the spatial scale decreases. The emissions over urban areas in East Asia and show better agreement in the temporal and spatial variability between the different inventories than over rural areas. The coarse-resolution EnKF inventories show low temporal correlation with other inventories over rural areas, because they are unable to distinguish between urban and rural sources at small scale. All the satellite-derived invento- ries except for DECSO-GOME2a show a summer peak over mainland China. The summer peak could be related to enhanced emissions from soils and biomass burning in summer, for which OMI better captures the enhanced concentrations than GOME-2 due to their different overpass time. All the satellite-derived inventories, in particular DECSO-OMI, are lower than bottom-up inventories at higher latitudes (at above $40^{\circ} \mathrm{N}$ ).

Based on our findings from the intercomparison of $\mathrm{NO}_{x}$ emission inventories, we come to the following recommendations for the development of $\mathrm{NO}_{x}$ emission inventories in the future:

- To better capture the temporal variability in emissions from the satellite-derived approach, observations from multiple instruments are important. In addition, a highspatial-resolution model is necessary to distinguish between different emission sources and to better derive the emissions on a small spatial scale.

- Different bottom-up inventories use different definition of emission sector categories and with different assumption about the shares of the different technologies and high uncertainties in $\mathrm{NO}_{x}$ emission factors and activities. Better measurements of emissions factors and more detailed statistics on the activities not only per fuel but also per (combustion) technology are required.

- To take into account the advantages of bottom-up and satellite-derived approaches and to update near-realtime emissions, sector information from the bottomup approach can be combined with the satellite-derived inventories. For instance, information on temporal changes of emissions from satellite-based calculations can be used for the temporal evolution of the bottom-up inventories.

- The satellite-derived approach can be further improved following the development of satellite instruments, like TROPOMI on Sentinel 5p and later the GEMS sensor on the geostationary GEO-KOMPSAT-2B. With higher spatial resolution of observations, more accurate emission over different land-use categories can be obtained. GEMS will provide observations with high temporal and spatial resolution, which enables the improvement of diurnal cycles for emission estimates.

Data availability. The $\mathrm{NO}_{x}$ emission data of DECSO are available on the webpage http://www.globemission.eu/region_asia/datapage. php. The $\mathrm{NO}_{x}$ emission data of EnKF can be obtained by contacting co-author Kazuyuki Miyazaki (kmiyazaki@jamstec.go.jp). The EDGAR inventory can be found on the webpage http://edgar.jrc.ec. europa.eu/overview.php? $\mathrm{v}=431$. The REAS v2.1 data can be found on the webpage http://www.nies.go.jp/REAS/. The REAS v2.2 data can be obtained by contacting co-author Jun-ichi Kurokawa 
(kurokawa@acap.asia). The MEIC data can be obtained via website http://www.meicmodel.org/. The CAPSS data can be obtained by contacting co-author SeogYeon Cho (sycho@inha.ac.kr).

Competing interests. The authors declare that they have no conflict of interest.

Acknowledgements. The research was part of the OMI project funded and supported by the Netherlands Space Office. We acknowledge IPSL/LMD, INERIS and IPSL/LISA in France for providing the CHIMERE model. We acknowledge the use of tropospheric $\mathrm{NO}_{2}$ column data obtained from www.temis.nl and the ESA GlobCover 2009 Project for the land-use dataset. We thank Henk Eskes and Folkert Boersma for their helpful suggestions.

Edited by: Ronald Cohen

Reviewed by: two anonymous referees

\section{References}

Akimoto, $\mathrm{H}$. and Narita, H.: Distribution of $\mathrm{SO}_{2}, \mathrm{NO}_{x}$ and $\mathrm{CO}_{2}$ emissions from fuel combustion and industrial activities in Asia with $1^{\circ} \times 1^{\circ}$ resolution, Atmos. Environ., 28, 213-225, https://doi.org/10.1016/1352-2310(94)90096-5, 1994.

Boersma, K. F., Eskes, H. J., and Brinksma, E. J.: Error analysis for tropospheric $\mathrm{NO}_{2}$ retrieval from space, J. Geophys. Res., 109, D04311, https://doi.org/10.1029/2003JD003962, 2004.

Boersma, K. F., Jacob, D. J., Eskes, H. J., Pinder, R. W., Wang, J., and van der A, R. J.: Intercomparison of SCIAMACHY and OMI tropospheric $\mathrm{NO}_{2}$ columns: Observing the diurnal evolution of chemistry and emissions from space, J. Geophys. Res., 113, D16S26, https://doi.org/10.1029/2007JD008816, 2008.

Boersma, K. F., Jacob, D. J., Trainic, M., Rudich, Y., DeSmedt, I., Dirksen, R., and Eskes, H. J.: Validation of urban $\mathrm{NO}_{2}$ concentrations and their diurnal and seasonal variations observed from the SCIAMACHY and OMI sensors using in situ surface measurements in Israeli cities, Atmos. Chem. Phys., 9, 3867-3879, https://doi.org/10.5194/acp-9-3867-2009, 2009.

Boersma, K. F., Eskes, H. J., Dirksen, R. J., van der A, R. J., Veefkind, J. P., Stammes, P., Huijnen, V., Kleipool, Q. L., Sneep, M., Claas, J., Leitão, J., Richter, A., Zhou, Y., and Brunner, D.: An improved tropospheric $\mathrm{NO}_{2}$ column retrieval algorithm for the Ozone Monitoring Instrument, Atmos. Meas. Tech., 4, 19051928, https://doi.org/10.5194/amt-4-1905-2011, 2011.

Bovensmann, H., Burrows, J. P., Buchwitz, M., Frerick, J., Noël, S., Rozanov, V. V., Chance, K. V., and Goede, A. P. H.: SCIAMACHY: Mission Objectives and Measurement Modes, J. Atmos. Sci., 56, 127-150, https://doi.org/10.1175/15200469(1999)056<0127:SMOAMM>2.0.CO;2, 1999.

Castellanos, P., Boersma, K. F., and van der Werf, G. R.: Satellite observations indicate substantial spatiotemporal variability in biomass burning $\mathrm{NO}_{x}$ emission factors for South America, Atmos. Chem. Phys., 14, 3929-3943, https://doi.org/10.5194/acp14-3929-2014, 2014.

Crippa, M., Janssens-Maenhout, G., Dentener, F., Guizzardi, D., Sindelarova, K., Muntean, M., Van Dingenen, R., and Granier,
C.: Forty years of improvements in European air quality: regional policy-industry interactions with global impacts, Atmos. Chem. Phys., 16, 3825-3841, https://doi.org/10.5194/acp-163825-2016, 2016.

Dee, D. P., Uppala, S. M., Simmons, A. J., Berrisford, P., Poli, P., Kobayashi, S., Andrae, U., Balmaseda, M. A., Balsamo, G., Bauer, P., Bechtold, P., Beljaars, A. C. M., van de Berg, L., Bidlot, J., Bormann, N., Delsol, C., Dragani, R., Fuentes, M., Geer, A. J., Haimberger, L., Healy, S. B., Hersbach, H., Hólm, E. V., Isaksen, L., Kållberg, P., Köhler, M., Matricardi, M., McNally, A. P., Monge-Sanz, B. M., Morcrette, J. J., Park, B. K., Peubey, C., de Rosnay, P., Tavolato, C., Thépaut, J. N., and Vitart, F.: The ERA-Interim reanalysis: configuration and performance of the data assimilation system, Q. J. Roy. Meteor. Soc., 137, 553-597, https://doi.org/10.1002/qj.828, 2011.

de Foy, B., Lu, Z., and Streets, D. G.: Satellite $\mathrm{NO}_{2}$ retrievals suggest China has exceeded its $\mathrm{NO}_{x}$ reduction goals from the twelfth Five-Year Plan, Scientific Reports, 6, 35912, https://doi.org/10.1038/srep35912, 2016.

Ding, J., van der A, R. J., Mijling, B., Levelt, P. F., and Hao, N.: $\mathrm{NO}_{x}$ emission estimates during the 2014 Youth Olympic Games in Nanjing, Atmos. Chem. Phys., 15, 9399-9412, https://doi.org/10.5194/acp-15-9399-2015, 2015.

Ding, J., van der A, R. J., Mijling, B., and Levelt, P. F.: Space-based $\mathrm{NO}_{x}$ emission estimates over remote regions improved in DECSO, Atmos. Meas. Tech., 10, 925-938, https://doi.org/10.5194/amt-10-925-2017, 2017.

Eder, B., Kang, D., Mathur, R., Pleim, J., Yu, S., Otte, T., and Pouliot, G.: A performance evaluation of the National Air Quality Forecast Capability for the summer of 2007, Atmos. Environ., 43, 2312-2320, https://doi.org/10.1016/j.atmosenv.2009.01.033, 2009.

FAO: Food and Agricultural Organization of the United Nations: Statistics Division, Livestock, Crop and Fertilizer data, available at: http://www.fao.org/docrep/015/i2490e/i2490e00.htm (last access: October 2016), 2012.

Gu, D., Wang, Y., Smeltzer, C., and Liu, Z.: Reduction in NOx Emission Trends over China: Regional and Seasonal Variations, Environ. Sci. Technol., 47, 12912-12919, https://doi.org/10.1021/es401727e, 2013.

He, K.: Multi-resolution Emission Inventory for China (MEIC): model framework and 1990-2010 anthropogenic emissions, in: International Global Atmospheric Chemistry Conference, Atmospheric Chemistry conference, Beijing, China, 17-21 September 2012.

IEA: Energy Statistics of OECD Countries 2014, IEA, Paris, available at: http://dx.doi.org/10.1787/energy_stats_oecd-2014-en (last access: 23 August 2017), 2014a.

IEA: Energy Statistics of Non-OECD Countries 2014, IEA, Paris, available at: http://dx.doi.org/10.1787/energy_ non-oecd-2014-en (last access: 23 August 2017), 2014b.

Irie, H., Sudo, K., Akimoto, H., Richter, A., Burrows, J. P., Wagner, T., Wenig, M., Beirle, S., Kondo, Y., Sinyakov, V. P., and Goutail, F.: Evaluation of long-term tropospheric $\mathrm{NO}_{2}$ data obtained by GOME over East Asia in 1996-2002, Geophys. Res. Lett., 32, L11810, https://doi.org/10.1029/2005GL022770, 2005.

Irie, H., Muto, T., Itahashi, S., Kurokawa, J.-i., and Uno, I.: Turnaround of Tropospheric Nitrogen Dioxide Pollution Trends 
in China, Japan, and South Korea, SOLA, 12, 170-174, https://doi.org/10.2151/sola.2016-035, 2016.

Jacob, D. J., Heikes, E. G., Fan, S. M., Logan, J. A., Mauzerall, D. L., Bradshaw, J. D., Singh, H. B., Gregory, G. L., Talbot, R. W., Blake, D. R., and Sachse, G. W.: Origin of ozone and $\mathrm{NO}_{x}$ in the tropical troposphere: A photochemical analysis of aircraft observations over the South Atlantic basin, J. Geophys. Res., 101, 24235-24250, https://doi.org/10.1029/96JD00336, 1996.

Jaegle, L., Steinberger, L., Martin, R. V., and Chance, K.: Global partitioning of $\mathrm{NO}_{x}$ sources using satellite observations: Relative roles of fossil fuel combustion, biomass burning and soil emissions, Faraday Discuss., 130, 407-423, https://doi.org/10.1039/B502128F, 2005.

Janssens-Maenhout, G., Pagliari, V., Guizzardi, D., and Muntean, M.: Global emission inventories in the Emission Database for Global Atmospheric Research (EDGAR) - Manual (I): Gridding: EDGAR emissions distribution on global gridmaps, JRC Technical Reports, 33 pp., https://doi.org/10.2788/81454, 2013.

Kanamitsu, M., Ebisuzaki, W., Woollen, J., Yang, S.-K., Hnilo, J. J., Fiorino, M., and Potter, G. L.: NCEP-DOE AMIPII Reanalysis (R-2), B. Am. Meteorol. Soc., 83, 1631-1643, https://doi.org/10.1175/bams-83-11-1631, 2002.

KNMI: Background information about the Row Anomaly in OMI, available at: http://projects.knmi.nl/omi/research/product/ rowanomaly-background, last access: 7 September 2012.

Konovalov, I. B., Beekmann, M., Richter, A., and Burrows, J. P.: Inverse modelling of the spatial distribution of $\mathrm{NO}_{x}$ emissions on a continental scale using satellite data, Atmos. Chem. Phys., 6, 1747-1770, https://doi.org/10.5194/acp-6-1747-2006, 2006.

Krotkov, N. A., McLinden, C. A., Li, C., Lamsal, L. N., Celarier, E. A., Marchenko, S. V., Swartz, W. H., Bucsela, E. J., Joiner, J., Duncan, B. N., Boersma, K. F., Veefkind, J. P., Levelt, P. F., Fioletov, V. E., Dickerson, R. R., He, H., Lu, Z., and Streets, D. G.: Aura OMI observations of regional $\mathrm{SO}_{2}$ and $\mathrm{NO}_{2}$ pollution changes from 2005 to 2015, Atmos. Chem. Phys., 16, 46054629, https://doi.org/10.5194/acp-16-4605-2016, 2016.

Kurokawa, J., Ohara, T., Morikawa, T., Hanayama, S., JanssensMaenhout, G., Fukui, T., Kawashima, K., and Akimoto, H.: Emissions of air pollutants and greenhouse gases over Asian regions during 2000-2008: Regional Emission inventory in ASia (REAS) version 2, Atmos. Chem. Phys., 13, 11019-11058, https://doi.org/10.5194/acp-13-11019-2013, 2013.

Lee, D., Lee, Y.-M., Jang, K.-W., Yoo, C., Kang, K.-H., Lee, J.-H., Jung, S.-W., Park, J.-M., Lee, S.-B., Han, J.S., Hong, J.-H., and Lee, S.-J.: Korean National Emissions Inventory System and 2007 Air Pollutant Emissions, Asian Journal of Atmospheric Environment, 5, 278-291, https://doi.org/10.5572/ajae.2011.5.4.278, 2011.

Levelt, P. F., van den Oord, G. H. J., Dobber, M. R., Malkki, A., Huib, V., de Vries, J., Stammes, P., Lundell, J. O. V., and Saari, H.: The ozone monitoring instrument, IEEE T. Geosci. Remote, 44, 1093-1101, https://doi.org/10.1109/TGRS.2006.872333, 2006.

Li, J., Li, Y., Bo, Y., and Xie, S.: High-resolution historical emission inventories of crop residue burning in fields in China for the period 1990-2013, Atmos. Environ., 138, 152-161, https://doi.org/10.1016/j.atmosenv.2016.05.002, 2016.

Li, M., Zhang, Q., Kurokawa, J.-I., Woo, J.-H., He, K., Lu, Z., Ohara, T., Song, Y., Streets, D. G., Carmichael, G. R., Cheng,
Y., Hong, C., Huo, H., Jiang, X., Kang, S., Liu, F., Su, H., and Zheng, B.: MIX: a mosaic Asian anthropogenic emission inventory under the international collaboration framework of the MICS-Asia and HTAP, Atmos. Chem. Phys., 17, 935-963, https://doi.org/10.5194/acp-17-935-2017, 2017.

Lin, J.-T.: Satellite constraint for emissions of nitrogen oxides from anthropogenic, lightning and soil sources over East China on a high-resolution grid, Atmos. Chem. Phys., 12, 2881-2898, https://doi.org/10.5194/acp-12-2881-2012, 2012.

Lin, J.-T., Liu, Z., Zhang, Q., Liu, H., Mao, J., and Zhuang, G.: Modeling uncertainties for tropospheric nitrogen dioxide columns affecting satellite-based inverse modeling of nitrogen oxides emissions, Atmos. Chem. Phys., 12, 12255-12275, https://doi.org/10.5194/acp-12-12255-2012, 2012.

Liu, F., Zhang, Q., Tong, D., Zheng, B., Li, M., Huo, H., and He, K. B.: High-resolution inventory of technologies, activities, and emissions of coal-fired power plants in China from 1990 to 2010, Atmos. Chem. Phys., 15, 13299-13317, https://doi.org/10.5194/acp-15-13299-2015, 2015.

Liu, F., Zhang, Q., van $\operatorname{der}$ A, R. J., Zheng, B., Tong, D., Yan, L., Zheng, Y., and He, K.: Recent reduction in NO $\mathrm{x}$ emissions over China: synthesis of satellite observations and emission inventories, Environ. Res. Lett., 11, 114002, https://doi.org/10.1088/1748-9326/11/11/114002, 2016.

Lorente, A., Folkert Boersma, K., Yu, H., Dörner, S., Hilboll, A., Richter, A., Liu, M., Lamsal, L. N., Barkley, M., De Smedt, I., Van Roozendael, M., Wang, Y., Wagner, T., Beirle, S., Lin, J.T., Krotkov, N., Stammes, P., Wang, P., Eskes, H. J., and Krol, M.: Structural uncertainty in air mass factor calculation for $\mathrm{NO}_{2}$ and HCHO satellite retrievals, Atmos. Meas. Tech., 10, 759-782, https://doi.org/10.5194/amt-10-759-2017, 2017.

Ma, J. and van Aardenne, J. A.: Impact of different emission inventories on simulated tropospheric ozone over China: a regional chemical transport model evaluation, Atmos. Chem. Phys., 4, 877-887, https://doi.org/10.5194/acp-4-877-2004, 2004.

Menut, L., Bessagnet, B., Khvorostyanov, D., Beekmann, M., Blond, N., Colette, A., Coll, I., Curci, G., Foret, G., Hodzic, A., Mailler, S., Meleux, F., Monge, J.-L., Pison, I., Siour, G., Turquety, S., Valari, M., Vautard, R., and Vivanco, M. G.: CHIMERE 2013: a model for regional atmospheric composition modelling, Geosci. Model Dev., 6, 981-1028, https://doi.org/10.5194/gmd-6-981-2013, 2013.

Mijling, B. and van der A, R. J.: Using daily satellite observations to estimate emissions of short-lived air pollutants on a mesoscopic scale, J. Geophys. Res., 117, D17302, https://doi.org/10.1029/2012JD017817, 2012.

Mijling, B., van der A, R. J., and Zhang, Q.: Regional nitrogen oxides emission trends in East Asia observed from space, Atmos. Chem. Phys., 13, 12003-12012, https://doi.org/10.5194/acp-1312003-2013, 2013.

Miyazaki, K. and Eskes, H.: Constraints on surface NOx emissions by assimilating satellite observations of multiple species, Geophys. Res. Lett., 40, 4745-4750, https://doi.org/10.1002/grl.50894, 2013.

Miyazaki, K., Eskes, H. J., and Sudo, K.: Global $\mathrm{NO}_{x}$ emission estimates derived from an assimilation of OMI tropospheric $\mathrm{NO}_{2}$ columns, Atmos. Chem. Phys., 12, 2263-2288, https://doi.org/10.5194/acp-12-2263-2012, 2012. 
Miyazaki, K., Eskes, H. J., Sudo, K., and Zhang, C.: Global lightning $\mathrm{NO}_{x}$ production estimated by an assimilation of multiple satellite data sets, Atmos. Chem. Phys., 14, 3277-3305, https://doi.org/10.5194/acp-14-3277-2014, 2014.

Miyazaki, K., Eskes, H., Sudo, K., Boersma, K. F., Bowman, K., and Kanaya, Y.: Decadal changes in global surface $\mathrm{NO}_{x}$ emissions from multi-constituent satellite data assimilation, Atmos. Chem. Phys., 17, 807-837, https://doi.org/10.5194/acp-17-8072017, 2017.

Müller, J.-F. and Stavrakou, T.: Inversion of $\mathrm{CO}$ and $\mathrm{NO}_{x}$ emissions using the adjoint of the IMAGES model, Atmos. Chem. Phys., 5, 1157-1186, https://doi.org/10.5194/acp-5-1157-2005, 2005.

Ohara, T., Akimoto, H., Kurokawa, J., Horii, N., Yamaji, K., Yan, X., and Hayasaka, T.: An Asian emission inventory of anthropogenic emission sources for the period 1980-2020, Atmos. Chem. Phys., 7, 4419-4444, https://doi.org/10.5194/acp-7-44192007, 2007.

Richter, A., Burrows, J. P., Nusz, H., Granier, C., and Niemeier, U.: Increase in tropospheric nitrogen dioxide over China observed from space, Nature, 437, 129-132, https://doi.org/10.1038/nature04092, 2005.

Saikawa, E., Kim, H., Zhong, M., Avramov, A., Zhao, Y., JanssensMaenhout, G., Kurokawa, J.-I., Klimont, Z., Wagner, F., Naik, V., Horowitz, L. W., and Zhang, Q.: Comparison of emissions inventories of anthropogenic air pollutants and greenhouse gases in China, Atmos. Chem. Phys., 17, 6393-6421, https://doi.org/10.5194/acp-17-6393-2017, 2017.

Schindlbacher, A., Zechmeister-Boltenstern, S., and ButterbachBahl, K.: Effects of soil moisture and temperature on $\mathrm{NO}, \mathrm{NO}_{2}$, and $\mathrm{N}_{2} \mathrm{O}$ emissions from European forest soils, J. Geophys. Res., 109, D17302, https://doi.org/10.1029/2004JD004590, 2004.

Shindell, D. T., Faluvegi, G., Koch, D. M., Schmidt, G. A., Unger, N., and Bauer, S. E.: Improved Attribution of Climate Forcing to Emissions, Science, 326, 716-718, https://doi.org/10.1126/science.1174760, 2009.

Sofiev, M., Vankevich, R., Lotjonen, M., Prank, M., Petukhov, V., Ermakova, T., Koskinen, J., and Kukkonen, J.: An operational system for the assimilation of the satellite information on wildland fires for the needs of air quality modelling and forecasting, Atmos. Chem. Phys., 9, 6833-6847, https://doi.org/10.5194/acp9-6833-2009, 2009.

Stavrakou, T., Müller, J.-F., Boersma, K. F., van der A, R. J., Kurokawa, J., Ohara, T., and Zhang, Q.: Key chemical $\mathrm{NO}_{x}$ sink uncertainties and how they influence top-down emissions of nitrogen oxides, Atmos. Chem. Phys., 13, 9057-9082, https://doi.org/10.5194/acp-13-9057-2013, 2013.

Stavrakou, T., Müller, J. F., Bauwens, M., De Smedt, I., Lerot, C., Van Roozendael, M., Coheur, P. F., Clerbaux, C., Boersma, K. F., van der A, R., and Song, Y.: Substantial Underestimation of PostHarvest Burning Emissions in the North China Plain Revealed by Multi-Species Space Observations, Scientific Reports, 6, 32307, https://doi.org/10.1038/srep32307, 2016.

Streets, D. G., Bond, T. C., Carmichael, G. R., Fernandes, S. D., Fu, Q., He, D., Klimont, Z., Nelson, S. M., Tsai, N. Y., Wang, M. Q., Woo, J. H., and Yarber, K. F.: An inventory of gaseous and primary aerosol emissions in Asia in the year 2000, J. Geophys. Res., 108, 8809, https://doi.org/10.1029/2002JD003093, 2003.

Streets, D. G., Canty, T., Carmichael, G. R., de Foy, B., Dickerson, R. R., Duncan, B. N., Edwards, D. P., Haynes, J. A., Henze, D.
K., Houyoux, M. R., Jacob, D. J., Krotkov, N. A., Lamsal, L. N., Liu, Y., Lu, Z., Martin, R. V., Pfister, G. G., Pinder, R. W., Salawitch, R. J., and Wecht, K. J.: Emissions estimation from satellite retrievals: A review of current capability, Atmos. Environ., 77, 1011-1042, https://doi.org/10.1016/j.atmosenv.2013.05.051, 2013.

Struzewska, J., Kaminski, J. W., and Jefimow, M.: Application of model output statistics to the GEM-AQ high resolution air quality forecast, Atmos. Res., 181, 186-199, https://doi.org/10.1016/j.atmosres.2016.06.012, 2016.

Sudo, K., Takahashi, M., Kurokawa, J.-i., and Akimoto, H.: CHASER: A global chemical model of the troposphere, 1. Model description, J. Geophys. Res., 107, 4339, https://doi.org/10.1029/2001JD001113, 2002.

Valin, L. C., Russell, A. R., Hudman, R. C., and Cohen, R. C.: Effects of model resolution on the interpretation of satellite $\mathrm{NO}_{2}$ observations, Atmos. Chem. Phys., 11, 11647-11655, https://doi.org/10.5194/acp-11-11647-2011, 2011.

Van Aardenne, J. A., Carmichael, G. R., Levy, H., Streets, D., and Hordijk, L.: Anthropogenic $\mathrm{NO}_{x}$ emissions in Asia in the period 1990-2020, Atmos. Environ., 33, 633-646, https://doi.org/10.1016/S1352-2310(98)00110-1, 1999.

van $\operatorname{der}$ A, R. J., Peters, D. H. M. U., Eskes, H., Boersma, K. F., Van Roozendael, M., De Smedt, I., and Kelder, H. M.: Detection of the trend and seasonal variation in tropospheric $\mathrm{NO}_{2}$ over China, J. Geophys. Res., 111, D12317, https://doi.org/10.1029/2005JD006594, 2006.

van $\operatorname{der}$ A, R. J., Mijling, B., Ding, J., Koukouli, M. E., Liu, F., Li, Q., Mao, H., and Theys, N.: Cleaning up the air: effectiveness of air quality policy for $\mathrm{SO}_{2}$ and $\mathrm{NO}_{x}$ emissions in China, Atmos. Chem. Phys., 17, 1775-1789, https://doi.org/10.5194/acp17-1775-2017, 2017.

van der Werf, G. R., Randerson, J. T., Giglio, L., Collatz, G. J., Mu, M., Kasibhatla, P. S., Morton, D. C., DeFries, R. S., Jin, Y., and van Leeuwen, T. T.: Global fire emissions and the contribution of deforestation, savanna, forest, agricultural, and peat fires (1997-2009), Atmos. Chem. Phys., 10, 11707-11735, https://doi.org/10.5194/acp-10-11707-2010, 2010.

Wang, Y., Beirle, S., Lampel, J., Koukouli, M., De Smedt, I., Theys, N., Li, A., Wu, D., Xie, P., Liu, C., Van Roozendael, M., Stavrakou, T., Müller, J.-F., and Wagner, T.: Validation of OMI, GOME-2A and GOME-2B tropospheric $\mathrm{NO}_{2}, \mathrm{SO}_{2}$ and $\mathrm{HCHO}$ products using MAX-DOAS observations from 2011 to 2014 in Wuxi, China: investigation of the effects of priori profiles and aerosols on the satellite products, Atmos. Chem. Phys., 17, 50075033, https://doi.org/10.5194/acp-17-5007-2017, 2017.

Wang, Y. X., McElroy, M. B., Wang, T., and Palmer, P. I.: Asian emissions of $\mathrm{CO}$ and $\mathrm{NO}_{x}$ : Constraints from aircraft and Chinese station data, J. Geophys. Res., 109, D24304, https://doi.org/10.1029/2004JD005250, 2004.

Watanabe, S., Hajima, T., Sudo, K., Nagashima, T., Takemura, T., Okajima, H., Nozawa, T., Kawase, H., Abe, M., Yokohata, T., Ise, T., Sato, H., Kato, E., Takata, K., Emori, S., and Kawamiya, M.: MIROC-ESM 2010: model description and basic results of CMIP5-20c3m experiments, Geosci. Model Dev., 4, 845-872, https://doi.org/10.5194/gmd-4-845-2011, 2011.

Yienger, J. J. and Levy, H.: Empirical model of global soilbiogenic $\mathrm{NO}_{x}$ emissions, J. Geophys. Res., 100, 11447-11464, https://doi.org/10.1029/95JD00370, 1995. 
Zhang, L., Liu, Y., and Hao, L.: Contributions of open crop straw burning emissions to $\mathrm{PM}_{2.5}$ concentrations in China, Environ. Res. Lett., 11, 014014, https://doi.org/10.1088/17489326/11/1/014014, 2016.

Zhang, Q., Streets, D. G., Carmichael, G. R., He, K. B., Huo, H., Kannari, A., Klimont, Z., Park, I. S., Reddy, S., Fu, J. S., Chen, D., Duan, L., Lei, Y., Wang, L. T., and Yao, Z. L.: Asian emissions in 2006 for the NASA INTEX-B mission, Atmos. Chem. Phys., 9, 5131-5153, https://doi.org/10.5194/acp-9-5131-2009, 2009.

Zhang, Y., Bocquet, M., Mallet, V., Seigneur, C., and Baklanov, A.: Real-time air quality forecasting, part II: State of the science, current research needs, and future prospects, Atmos. Environ., 60, 656-676, https://doi.org/10.1016/j.atmosenv.2012.02.041, 2012.

Zhao, C. and Wang, Y.: Assimilated inversion of NOx emissions over east Asia using $\mathrm{OMI} \mathrm{NO}_{2}$ column measurements, Geophys. Res. Lett., 36, L06805, https://doi.org/10.1029/2008GL037123, 2009.
Zhao, Y., Nielsen, C. P., Lei, Y., McElroy, M. B., and Hao, J.: Quantifying the uncertainties of a bottom-up emission inventory of anthropogenic atmospheric pollutants in China, Atmos. Chem. Phys., 11, 2295-2308, https://doi.org/10.5194/acp-112295-2011, 2011.

Zheng, B., Huo, H., Zhang, Q., Yao, Z. L., Wang, X. T., Yang, X. F., Liu, H., and He, K. B.: High-resolution mapping of vehicle emissions in China in 2008, Atmos. Chem. Phys., 14, 9787-9805, https://doi.org/10.5194/acp-14-9787-2014, 2014.

Zörner, J., Penning de Vries, M., Beirle, S., Sihler, H., Veres, P. R., Williams, J., and Wagner, T.: Multi-satellite sensor study on precipitation-induced emission pulses of $\mathrm{NO}_{x}$ from soils in semi-arid ecosystems, Atmos. Chem. Phys., 16, 9457-9487, https://doi.org/10.5194/acp-16-9457-2016, 2016. 